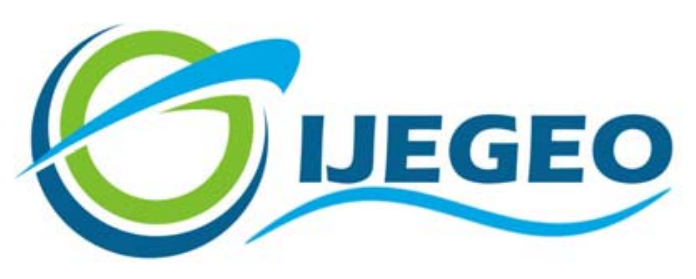

International Journal of Environment and Geoinformatics (IJEGEO) is an international, multidisciplinary, peer reviewed, open access journal.

\title{
A review on heavy metal levels in sea cucumbers
}

\section{Levent BAT, Quratulan AHMED, Ayşah ÖZTEKIN, Elif ARICI}

\author{
Chief in Editor \\ Prof. Dr. Cem Gazioğlu \\ Co-Editors \\ Prof. Dr. Dursun Zafer Şeker, Prof. Dr. Şinasi Kaya, \\ Prof. Dr. Ayşegül Tanık and Assist. Prof. Dr. Volkan Demir
}

\section{Editorial Committee (December 2020)}

Assos. Prof. Dr. Abdullah Aksu (TR), Assit. Prof. Dr. Uğur Algancı (TR), Prof. Dr. Bedri Alpar (TR), Prof. Dr. Levent Bat (TR), Prof. Dr. Paul Bates (UK), İrşad Bayırhan (TR), Prof. Dr. Bülent Bayram (TR), Prof. Dr. Luis M. Botana (ES), Prof. Dr. Nuray Çağlar (TR), Prof. Dr. Sukanta Dash (IN), Dr. Soofia T. Elias (UK), Prof. Dr. A. Evren Erginal (TR), Assoc. Prof. Dr. Cüneyt Erenoğlu (TR), Dr. Dieter Fritsch (DE), Prof. Dr. Çiğdem Göksel (TR), Prof.Dr. Lena Halounova (CZ), Prof. Dr. Manik Kalubarme (IN), Dr. Hakan Kaya (TR), Assist. Prof. Dr. Serkan Kükrer (TR), Assoc. Prof. Dr. Maged Marghany (MY), Prof. Dr. Michael Meadows (ZA), Prof. Dr. Nebiye Musaoğlu (TR), Prof. Dr. Masafumi Nakagawa (JP), Prof. Dr. Hasan Özdemir (TR), Prof. Dr. Chryssy Potsiou (GR), Prof. Dr. Erol Sarı (TR), Prof. Dr. Maria Paradiso (IT), Prof. Dr. Petros Patias (GR), Prof. Dr. Elif Sertel (TR), Prof. Dr. Nüket Sivri (TR), Prof. Dr. Füsun Balık Şanlı (TR), Prof. Dr. Uğur Şanlı (TR), Duygu Ülker (TR), Prof. Dr. Seyfettin Taş (TR), Assoc. Prof. Dr. Ömer Suat Taşkın (US), Assist. Prof. Dr. Tuba Ünsal (US), Dr. İnese Varna (LV), Dr. Petra Visser (NL), Prof. Dr. Selma Ünlü (TR), Prof. Dr. Murat Yakar (TR), Assit. Prof. Dr. Sibel Zeki (TR)

Abstracting and Indexing: TR DIZIN, DOAJ, Index Copernicus, OAJI, Scientific Indexing Services, International Scientific Indexing, Journal Factor, Google Scholar, Ulrich's Periodicals Directory, WorldCat, DRJI, ResearchBib, SOBIAD 


\title{
A review on heavy metal levels in sea cucumbers
}

\author{
Levent BAT ${ }^{1, *}$ iD), Quratulan AHMED ${ }^{2}$ iD, Ayşah ÖZTEKİN ${ }^{1}$ iD, Elif ARICI $^{3}$ \\ ${ }^{1}$ Sinop University Fisheries Faculty, Department of Hydrobiology, TR57000 Sinop, Turkey \\ ${ }^{2}$ The Marine Reference Collection and Resource Centre, University of Karachi, 75270 Karachi, Pakistan \\ ${ }^{3}$ Vocational School of Health Services, University of Sinop, Turkey \\ * Corresponding author: L. BAT \\ * E-mail: leventbat@gmail.com \\ Received 08 May 2020 \\ Accepted 10 Sep 2020
}

How to cite: Bat et al., (2020). A review on heavy metal levels in sea cucumbers, International Journal of Environment and Geoinformatics (IJEGEO), 7(3): 252-264. DOI: 10.30897/ijegeo.734402

\begin{abstract}
Heavy metals can remain in the marine ecosystems for a long time, they may affect biota in the food chain as a result. Sometimes the existence of xenobiotics causes so great a alter in the ecosystem that a return to earlier, natural conditions is not viable. Human pressure on the sea's resources is increasing, it affects the health of many organisms, leading to changes in the food chains and influencing accumulation in the tissues of biota. Sea cucumbers are being used for heavy metal pollution studies. They are preferred with their many features such as easy collection from the land, feeding with organic matter, contact with sediment, maintenance in laboratories, obtaining sufficient tissue, consuming some species. This review covers heavy metal studies with sea cucumbers in different seas. The results are compared with each other. In addition, the evaluation of the consumed sea cucumber species in terms of human health has been discussed.
\end{abstract}

Keywords: Sea cucumbers, metals, bioindicator, accumulation, monitoring

\section{Introduction}

Marine pollution is the entrance of contaminants into the sea, and includes mainly the dumping of domestic, industrial, agricu1tural and chemical wastes, oil spills from ships and wastes from fishing and touristic activities. The outcomes of marine pollution range from short-term economic losses owing to the unsightly fouling of coasts by litter, oil spills, microplastics and other floatable substances to lesser noticeable but longer-term effects on the whole ecosystem. The most of the accidental and deliberate incidents of marine contamination occur mostly in the coastal ecosystems.

Marine coastal ecosystems are heavily inhabited areas because of the extensive range of economic possibilities attracting industry, new residential growths and other anthropogenic activities that affect coastal ecosystems mainly by waste or sewer discharge to coast, causing pollution. Coastal areas are complex and dynamic ecosystems. Unfortunately, many chemicals are discarded or discharged to seas, especially the shores, which are the final receiving environment (Bat et al., 2018; Balkıs et al., 2017; Burak et al., 2009). Pollution status is determined by meteorological and oceanographic processes that tend to modify the contaminant's amount over time and space. The ecological component is explained as the effects that contaminant amounts have on marine organisms. The most important of these are heavy metals. Heavy metals tend to accumulate in water, sediment and biota in the marine ecosystem (Bryan, 1976; Phillips and Rainbow, 1994; Gazioğlu, 2018). Heavy metal levels in marine organisms are generally significantly higher than other components of the marine environment. Due to their ability to concentrate heavy metals from their habitats, it is important to know the changes in metal levels that should be considered in a normal range, and to know how much their levels can be increased above these levels before commercial species become suitable for food (Ober et al., 1987). Farrington et al. (1987) indicated that the two principal reasons for evaluating the status of chemical contamination in coastal environment were: to keep human health safe and estimate the exposure via the way back to man to protect valuable living natural sources. Many metals are important for organisms, results in their absence an organism can neither grow nor reproduce. However, non-essential metals are not useful at any concentration. All metals, whether essential or not, accumulate in their bodies by marine organisms. Heavy metals can damage aquatic organisms if they are above a certain level. It can even put human health at a significant risk through the food chain.

Heavy metals reaching the sea eventually sink to the bottom (Bat and Özkan, 2019) and affect benthic organisms the most (Bat and Arici, 2018). This can cause heavy metals accumulated in sediments in contaminated areas to accumulate by sea cucumbers (Ahmed et al., 2018a; Fretes et al., 2020), since some sea cucumbers are non-selective deposit feeder, and are mainly found in the bottom of sea waters (Xing and Chia, 1997).

There are many studies on heavy metals in sea cucumbers from across the world and these studies are increasing 
rapidly. The main object of the review to compare the metal concentrations in sea cucumber species from other regions of the World and evaluate the results in terms of human health.

\section{Importance of sea cucumbers}

Sea cucumbers are unusual marine invertebrates and belonging to the phylum Echinodermata, and are found in the benthic zones and deep seas across the world (Bordbar et al., 2011). The number of holothurian species worldwide is about 1250 with the greatest number being in the Asia Pacific region (Du et al., 2012). They are major component of the marine ecosystem. The scientific names, habitat, consumption and distribution of common sea cucumber species are given in Table 1.

They are significant member of the marine ecosystem and distributed all oceans of the world, habitually living near corals, rocks, sea weeds in warm shallow waters (Ridzwan, 2007; Higgins, 2000). Sea cucumbers are usually soft bodied, elongated, worm like animal with a leathery skin and gelatinous body animal. They are generally scavengers, feeding on organic substances and mud, which they catch with their tentacles in the benthic zone of the marine ecosystems. They play important roles in the marine ecosystem as they accelerate recycle nutrients, breaking down detritus and other organic matter later which bacteria can proceed the degradation process (Du et al., 2012). Behavior and biology of sea cucumbers have major effects on physico-chemical processes of softbottom and reef ecosystems (Purcell et al., 2016). Gao et al., (2014) found that selective feeding of the sea cucumber Apostichopus japonicus was the primary source of the different bacterial communities between the foregut contents and surrounding sediments. Purcell et al. (2016) pointed out the role of sea cucumbers sedimentclearing in modified coastal habitats. Moreover, İşgörenEmiroğlu and Günay (2007) noted that sea cucumbers such as Holothuria tubulosa may both eliminate biological pollution and recover water quality in fish farming areas. Hence, it was recommended a polyculture of fish and sea cucumber might be realized in future (İşgören-Emiroğlu and Günay, 2007).

The use of sea cucumbers as a food item and a commodity began in China about 1000 years ago (Purcell et al., 2012). A total of 58 consumed sea cucumber species are well defined (Purcell et al., 2012). Especially, Stichopus hermanni, Thelenota ananas, Thelenota anax, Holothuria fuccogilva and Actinopyga mauritiana are used for human consumption mainly in Asia countries (Lin et al., 2018; Pangestuti and Arifin, 2018) and some species are cultivated in aquaculture systems (Zamora et al., 2016). They are traditionally consumed raw, dried, and boiled in many tropical and subtropical countries (Özer et al., 2004; Rasyid, 2017). Sea cucumbers fishery provide an essential source of income for developing countries (Bordbar et al., 2011). They contain large amounts of nutrients such as Vitamin A, Vitamin B and minerals, proteins, fatty and amino acids (Özer et al., 2004; Bordbar et al., 2011; Haider et al., 2015; Pangestuti and Arifin, 2018). Also, they are using in biological and pharmacological activities including such as anti-angiogenic, anticancer, anticoagulant, anti-hypertension, anti-inflammatory, antimicrobial, antioxidant, antithrombotic, antitumor and wound healing (Bordbar et al., 2011; Pangestuti and Arifin, 2018).

Sea cucumbers have been fishing commercially for many years (Bordbar et al., 2011). They are very targeted and high nutritional value fisheries resource in the inshore subsistence fishery so it is very important to the local communities harvesting these resources for continuation of life. All over the world sea cucumber catch abundantly in the tropical region and the total annual global catch is in the order of 100,000 tons of live animals (ToralGranda, 2008; Purcell, 2010). The major fisheries exist in China, Ecuador, Indonesia, Japan, Republic of Korea, Malaysia, Philippines, Madagascar, Australia and New Caledonia. Recently, abundance and distributions (Ahmed and Ali, 2014), the length-weight relationships and condition assessments (Ahmed et al., 2018a), sexual reproduction (Ahmed et al., 2018b) and rediscoveries (Ahmed and Ali, 2020) of sea cucumber species in the Pakistani coasts of the Arabian Sea have been intensively studied.

\section{Metals in sea cucumber species}

Comparisons were made with levels reported in the literature for sea cucumbers from elsewhere, where possible, on those from different waters (Table 2).

\section{Cd in sea cucumbers}

Warnau et al. (2006) found a maximum value of $2.84 \pm 1.25 \mathrm{mg} / \mathrm{kg}$ dry wt. in Holothuria tubulosa collected from the Calvi Bay in Corsica. Cd levels reported in Tale 2 for Acaudina leucoprocta $(0.05 \pm 0.01$ $\mathrm{mg} / \mathrm{kg}$ dry wt.) from Xiangshan China (Lin et al., 2018), Actinopyga lecanora $(0.02 \mathrm{mg} / \mathrm{kg})$, Stichopus vastus $(0.04 \mathrm{mg} / \mathrm{kg})$ and Thelenota anax $(0.04 \mathrm{mg} / \mathrm{kg})$ from Sabah Malaysia (Hashmi et al., 2014), Actinopyga miliaris $(0.05266 \pm 0.01361 \mathrm{mg} / \mathrm{kg}$ dry wt.), Bohadschia similis $(0.05497 \pm 0.03079 \mathrm{mg} / \mathrm{kg}$ dry wt.), Holothuria scabra $(0.04162 \pm 0.00695 \mathrm{mg} / \mathrm{kg}$ dry wt.) and Holothuria spinifera $(0.048 .3 \pm 0.01242 \mathrm{mg} / \mathrm{kg}$ dry wt.) from Sri Lanka (Jinadasa et al., 2014) were significantly lower. Moreover, Cd levels were below the limit of detection for Actinopyga mauritiana and Holothuria arenicola from Pakistan (Haider et al., 2015).

\section{$\mathrm{Cu}$ in sea cucumbers}

$\mathrm{Cu}$ levels have shown considerable variations in sea cucumber species. The highest concentrations occurred in Holothuria leucospilota $(97.69 \pm 0.61 \mathrm{mg} / \mathrm{kg}$ dry wt.) and Holothuria scabra $(81.16 \pm 1.05 \mathrm{mg} / \mathrm{kg}$ dry wt.) from Qeshm Island, Persian Gulf (Mohammadizadeh et al., 2016). This was followed by Holothuria fuscopunctata with a value of $74 \pm 9 \mathrm{mg} / \mathrm{kg}$ dry wt. from Guangzhou in China (Wen and $\mathrm{Hu}, 2010$ ). 


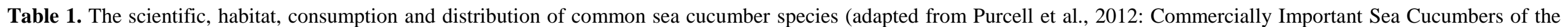
World Catalogue).

\begin{tabular}{|c|c|c|c|c|}
\hline Species & & Habitat & Consumption & Distribution \\
\hline $\begin{array}{l}\text { Acaudina leucoprocta } \\
\text { (H.L. Clark, 1938) }\end{array}$ & & $\begin{array}{llll}\text { It is distributed between } & 0-31 & \mathrm{~m} . \\
\text { (Anonymous, 2020a) }\end{array}$ & $\begin{array}{l}\text { Yes (Lin et al., } \\
\text { 2017) }\end{array}$ & $\begin{array}{l}\text { Tropical, east Indo-west Pacific ocean, and also distributed in Australia (Anonymous, } \\
\text { 2020a) }\end{array}$ \\
\hline $\begin{array}{l}\text { Actinopyga bannwarthi } \\
\text { Panning, } 1944\end{array}$ & & $\begin{array}{l}\text { It is distributed shallow waters (Anonymous, } \\
2020 \mathrm{a} \text { ) }\end{array}$ & Unknown & $\begin{array}{l}\text { Indian ocean, Madagascar and Red Sea also distributed in SE Arabia, Australia } \\
\text { (Anonymous, 2020a) }\end{array}$ \\
\hline $\begin{array}{l}\text { Actinopyga caerulea } \\
\text { Samyn, VandenSpiegel } \\
\text { Massin, } 2006\end{array}$ & $\&$ & $\begin{array}{l}\text { This species is characteristic of somewhat } \\
\text { deeper tropical waters; it has been observed } \\
\text { from } 12 \text { to } 45 \mathrm{~m} \text { (Conand et al., 2013) }\end{array}$ & Yes & $\begin{array}{l}\text { Comoros; Indonesia; Mayotte; New Caledonia; Papua New Guinea; Philippines; } \\
\text { Solomon Islands; Taiwan, Province of China; Thailand (Conand et al., 2013) }\end{array}$ \\
\hline $\begin{array}{l}\text { Actinopyga lecanora } \\
\text { (Jaeger, 1835) }\end{array}$ & & $\begin{array}{l}\text { It lives in coral and coral rocks and reef } \\
\text { ledges, between } 0.5 \text { and } 7 \mathrm{~m} \text {. It prefers hard } \\
\text { substrates (i.e. coral reefs) }\end{array}$ & Yes & $\begin{array}{l}\text { The Mascarene Islands, East Africa to the Red Sea and Oman, Madagascar, Sri Lanka, } \\
\text { Bay of Bengal, East Indies, north Australia, the Philippines, China and southern Japan, } \\
\text { South Pacific Islands. In India, it is found only in Andamans and Lakshadweep regions }\end{array}$ \\
\hline $\begin{array}{l}\text { Actinopyga mauritiana } \\
\text { (Quoy and Gaimard, 1833) }\end{array}$ & & $\begin{array}{l}\text { Prefers outer reef flats and fringing reefs, in } \\
\text { very shallow waters, near low water mark } \\
\text { where surf breaks, generally in } 1-3 \mathrm{~m} \text { water } \\
\text { depth. }\end{array}$ & Yes & $\begin{array}{l}\text { Islands of western Indian Ocean, Mascarene Islands, East Africa, Madagascar, Red Sea, } \\
\text { Maldives, Sri Lanka, Bay of Bengal, East Indies, north Australia, the Philippines, China } \\
\text { and southern Japan, South Pacific Islands (see SPC PROCFish/C surveys) as far east as } \\
\text { Pitcairn Islands. In India, it is distributed in the Gulf of Mannar, the Andamans and } \\
\text { Lakshadweep. }\end{array}$ \\
\hline $\begin{array}{l}\text { Actinopyga miliaris } \\
\text { (Quoy and Gaimard, 1833) }\end{array}$ & & $\begin{array}{l}\text { It is distributed commonly between } 0 \text { and } 10 \\
\mathrm{~m} \text { deep, on sandy beds and intertidal areas. }\end{array}$ & Yes & $\begin{array}{l}\text { Islands of western Indian Ocean, Mascarene Islands, East Africa, Madagascar, Red Sea, } \\
\text { Sri Lanka, Bay of Bengal, East Indies, north Australia, the Philippines, China and } \\
\text { southern Japan, South Pacific Islands east to French Polynesia. In India, it is known } \\
\text { from the Gulf of Mannar, Palk Bay, the Andamans and Lakshadweep. }\end{array}$ \\
\hline $\begin{array}{l}\text { Apostichopus japonicus } \\
\text { (Selenka, 1867) }\end{array}$ & & $\begin{array}{l}\text { It occurs from the shallows of the intertidal } \\
\text { zone to about } 20 \text { or } 30 \mathrm{~m} \text { depth. }\end{array}$ & Yes & $\begin{array}{l}\text { Western Pacific Ocean, the Yellow Sea, the Sea of Japan, the Sea of Okhotsk. The } \\
\text { northern limits of its geographic distribution are the coasts of Sakhalin Island, Russian } \\
\text { Federation and Alaska (USA). The southern limit is Tanega-shima in Japan. In China, } \\
\text { it is commonly distributed on the coast of Liaoning, Hebei and Shandong Province, } \\
\text { Yantai and Qingdao of Shandong Province. Its southern limit in China is Dalian Island } \\
\text { in Lian Yungang, Jiangsu Province. }\end{array}$ \\
\hline $\begin{array}{l}\text { Bohadschia argus } \\
\text { Jaeger, } 1833\end{array}$ & & $\begin{array}{l}\text { A typical reef species. Generally occurs in } 2 \\
\text { to } 10 \mathrm{~m} \text { depth on reef flats and back reef } \\
\text { lagoons with clear water. }\end{array}$ & Yes & $\begin{array}{l}\text { Sri Lanka, Bay of Bengal, East Indies, north Australia, the Philippines, China and } \\
\text { southern Japan, south Pacific Islands. In India, it is distributed in the Andamans and } \\
\text { Lakshadweep regions and occurs in the far eastern Indian Ocean to French Polynesia in } \\
\text { the Pacific. }\end{array}$ \\
\hline $\begin{array}{l}\text { Bohadschia marmorata } \\
\text { Jaeger, } 1833\end{array}$ & & $\begin{array}{l}\text { Occurs in shallow water rarely deeper than } 3 \\
\mathrm{~m} \text {. Inhabits seagrass beds in muddy-sand } \\
\text { sediments, in sheltered or semisheltered } \\
\text { sites. }\end{array}$ & Yes & $\begin{array}{l}\text { Mascarene Islands, East Africa, Madagascar, Red Sea, Sri Lanka, Bay of Bengal, East } \\
\text { Indies, north Australia, the Philippines, China and southern Japan, South Pacific Islands. } \\
\text { Widely distributed in Southeast Asia and the Pacific Islands, where its reported range } \\
\text { extends to French Polynesia in the east. Occurs throughout the Indian Ocean to East } \\
\text { Africa. }\end{array}$ \\
\hline $\begin{array}{l}\text { Bohadschia similis } \\
\text { (Semper, 1868) }\end{array}$ & & $\begin{array}{l}\text { This species is reef associated. It can be } \\
\text { found in very shallow waters, and occurs in } \\
\text { coastal lagoons and inner reef flats, generally } \\
\text { burrowing in sandy-muddy bottoms between } \\
\text { 0-3m (Kinch et al. 2008, Purcell et al. 2008; } \\
\text { taken from Samyn, 2013) }\end{array}$ & (Samyn, & $\begin{array}{l}\text { American Samoa; Australia; Brunei Darussalam; Cambodia; Cook Islands; Fiji; French } \\
\text { Polynesia; Guam; Indonesia; Kenya; Kiribati; Malaysia; Marshall Islands; Mauritius; } \\
\text { Micronesia, Federated States of ; Myanmar; Nauru; New Caledonia; Niue; Northern } \\
\text { Mariana Islands; Palau; Papua New Guinea; Philippines; Pitcairn; Réunion; Samoa; } \\
\text { Singapore; Solomon Islands; Somalia; Thailand; Timor-Leste; Tokelau; Tonga; Tuvalu; } \\
\text { Vanuatu; Viet Nam; Wallis and Futuna (Samyn, 2013) }\end{array}$ \\
\hline $\begin{array}{l}\text { Bohadschia vitiensis } \\
\text { (Semper, 1868) }\end{array}$ & & $\begin{array}{l}\text { Found in shallow waters, rarely in depths of } \\
\text { more than } 20 \mathrm{~m} \text {. Mostly in sheltered coastal } \\
\text { lagoons and inner reef flats on sand or } \\
\text { occasionally among rubble and coral patches. }\end{array}$ & Yes & $\begin{array}{l}\text { Widely distributed in the Indo-Pacific, being reported as far east as French Polynesia } \\
\text { and west to Madagascar and eastern Africa. }\end{array}$ \\
\hline
\end{tabular}




\begin{tabular}{l} 
Holothuria arenicola \\
Semper, 1868 \\
\hline $\begin{array}{l}\text { Holothuria cinerascens } \\
\text { (Brandt, 1835) }\end{array}$
\end{tabular}

Holothoria edulis

Lesson, 1830

Abundant in intertidal and shallow areas but

can also be found in deeper waters. It can be found under stones, in coral debris and on sand flats.

It lives in the outer reef over hard substratum generally between 0 and $3 \mathrm{~m}$, but believed to be found at up to $20 \mathrm{~m}$ depth.

Found mostly on silty-sand or sand mixed with coral rubble. Occupies semi-sheltered reef habitats, namely reef flats and lagoon patch rects near the coast from 0 to 20 in depth.

Holothuria fuscogilva

Cherbonnier, 1980

Holothuria fuscopunctata Commonly inhabits outer barrier reef slopes, reef passes and sandy areas in semi-sheltered reef habitats in 10 to $50 \mathrm{~m}$ water depth.

$\begin{array}{ll}\text { Jaeger, } 1833 & \text { It lives in shallow waters, generally from } 3 \\ & 25 \mathrm{~m} \text { depth. Inhabits reef slopes, lagoons an }\end{array}$ seagrass beds over sandy bottoms. Generally found on coarse sand or coral rubble.

Holothuria impatiens It lives in shallow coral reef habitats. In the (Forsskål, 1775) Comoros and Mascarene Islands, it can be found under rocks in shallow waters between 0 and $2 \mathrm{~m}$; however, it can be observed up to $30 \mathrm{~m}$ depth.

Holothuria leucospilota Brandt, 1835

Lives in shallow habitats up to $10 \mathrm{~m}$ depth. Found mostly on outer and inner reef flats, back reefs and shallow coastal lagoons Commonly found in seagrass beds, sandy and muddy bottoms with rubble or coral reefs.

Holothuria mexicana In Colombia, this species prefers coral reefs, seagrass beds, sandy or rubble bottoms and mangrove habitats. In the wider Caribbean, it inhabits shallow waters with sandy or coral

patches or seagrass beds.

Holothuria pardalis

Selenka, 1867

In Kenya, it has been observed buried under coral rubble or corl Comoros, it in or 0 and $10 \mathrm{~m}$ depith shallow waters between among coral rubble. In La Réunion, it is found in crevices on reef flats.
Yes

(ne

Widespread in the Indo-Pacific. This species is found at Mascarene Islands, East Africa, Madagascar, Red Sea, southeast Arabia, Persian Gulf, Maldives, Sri Lanka, Bay of Bengal, India, North Australia, the Philippines, China and southern Japan, South Sea Islands, Hawaiian Islands. It can be found in the islands in the central and eastern tropical Pacific, including Coco and Galápagos islands, Panama region, Clipperton Island and Mexico.

This species is believed to be found at some localities in the Western Pacific, parts of Asia, and the Indian Ocean, including the Red Sea and the Comoros. Reported along the Pacific coast of Central America. This species is reported from the Caribbean and Brazil, but those sightings probably represent a different species.

The gonads of this species are eaten in subsistence fisheries. The body wall is also consumed by Asians.

$\begin{array}{ll}\text { Yes } & \begin{array}{l}\text { The gonads of this } \\ \text { consumed by Asians. }\end{array}\end{array}$

Yes $\quad$ East Africa, Madagascar, Red Sea, southeast Arabia, Sri Lanka, Bay of Bengal, East Indies, North Australia, the Philippines, China and southern Japan, South Sea Islands. In India, this species is distributed in the Gulf of Mannar and the Andamans. Widespread in the Pacific and Southeast Asia, extending to French Polynesia in the southeast and Hawaii in the northeast.

Yes Mostly, the reconstituted body wall (bêche-de-mer) is consumed by Asians and is highly regarded.

Yes

Yes

It can be found in the western central Pacific, Asia and the Africa and Indian Ocean and also occurs at least as far east as Tonga.

Yes

It can be found from East Africa and the Indian Ocean to the western central Pacific including Hawaii, in the Pitcairn Islands group, and including much of the Pacific coast of Central America.

Yes

This species has one of the broadest distributions of all holothurians, and it can be found in most tropical localities in the western central Pacific, Asia and most Indian Ocean regions.

Distributed widely along the Florida Keys, Bahama Islands, Cuba, Puerto Rico, Jamaica, Barbados, Tobago, Aruba, Yucatan Peninsula, Belize, Bonaire, Venezuela (Bolivarian Republic of) and islands off Colombia, at depths from 0.5 to $20 \mathrm{~m}$.

Ranges from the western central Pacific to the Hawaiian Islands, Asia and the Africa and Indian Ocean region. Also found on the Pacific coast of Central America. $30^{\circ} \mathrm{S}$ and not found further east than Fiji. 
coastal sandflats and seagrass beds with muddy sandy substrates, near mangroves

\begin{tabular}{|c|c|c|c|}
\hline $\begin{array}{l}\text { Holothuria spinifera } \\
\text { Théel, } 1886\end{array}$ & $\begin{array}{l}\text { It can completely bury itself in sand in } \\
\text { shallow waters from } 2 \text { to } 10 \mathrm{~m} \text {. }\end{array}$ & Yes & $\begin{array}{l}\text { Red Sea, Persian Gulf, Sri Lanka, northern Australia, the Philippines. In India, it is } \\
\text { known only from Gulf of Mannar and Palk Bay. }\end{array}$ \\
\hline $\begin{array}{l}\text { Holothuria tubulosa } \\
\text { Gmelin, } 1791\end{array}$ & $\begin{array}{l}\text { This species is found in seagrass beds with } \\
\text { larger individuals occurring at the deepest } \\
\text { depths of the beds (Bulteel et al. 1992, } \\
\text { Coulon and Jangoux 1993) (Samyn, 2013) }\end{array}$ & $\begin{array}{l}\text { There is a } \\
\text { commercial } \\
\text { fishery in Turkey } \\
\text { (Aydin, 2008) }\end{array}$ & $\begin{array}{l}\text { Albania; Algeria; Belgium; Bosnia and Herzegovina; Croatia; Cyprus; Egypt; France; } \\
\text { Gibraltar; Greece; Guernsey; Ireland; Israel; Italy; Jersey; Lebanon; Libya; Malta; } \\
\text { Monaco; Montenegro; Morocco; Portugal (Portugal (mainland), Azores); Slovenia; } \\
\text { Spain; Syrian Arab Republic; Tunisia; Turkey; United Kingdom (Northern Ireland, } \\
\text { Great Britain) (Samyn, 2013) }\end{array}$ \\
\hline $\begin{array}{l}\text { Holothuria verrucosa } \\
\text { Selenka, } 1867\end{array}$ & $\begin{array}{l}\text { It is a cryptic species that is found buried in } \\
\text { sand, seagrasses and rubble (Conand et al., } \\
\text { 2013) }\end{array}$ & $\begin{array}{l}\text { low commercial } \\
\text { value, } \\
\text { may be locally } \\
\text { consumed } \\
\text { (Conand et al., } \\
\text { 2013) }\end{array}$ & $\begin{array}{l}\text { American Samoa; Australia; China; Cook Islands; Djibouti; Egypt; Eritrea; Fiji; French } \\
\text { Polynesia; Guam; Indonesia; Israel; Jordan; Kenya; Kiribati; Madagascar; Malaysia; } \\
\text { Marshall Islands; Micronesia, Federated States of ; Nauru; New Caledonia; New } \\
\text { Zealand; Niue; Northern Mariana Islands; Palau; Papua New Guinea; Philippines; } \\
\text { Samoa; Saudi Arabia; Seychelles; Singapore; Solomon Islands; Sudan; Taiwan, } \\
\text { Province of China; Tanzania, United Republic of; Thailand; Tokelau; Tonga; Tuvalu; } \\
\text { United States (Hawaiian Is.); Vanuatu; Viet Nam; Wallis and Futuna; Yemen (Conand } \\
\text { et al., 2013) }\end{array}$ \\
\hline $\begin{array}{l}\text { Ohshimella ehrenbergii } \\
\text { (Selenka, 1868) }\end{array}$ & $\begin{array}{lrrrr}\text { In rock revices } & \text { or } & \text { under } & \text { stones } \\
\text { (Anonymous, 2020a) } & & & \end{array}$ & Unknown & $\begin{array}{l}\text { distributed in SE Arabia, W India, Pakistan, Maldive area and Ceylon (Clark \& Rowe, } \\
\text { 1971).From India, Maldives and Ceylon, round Arabia to the Red Sea and east coast of } \\
\text { Africa (Anonymous, 2020a) }\end{array}$ \\
\hline $\begin{array}{l}\text { Phyllophorus } \\
\text { Chang, } 1935\end{array}$ & $\begin{array}{l}\text { depth range } 0-30 \mathrm{~m} \text {. It lives in aggregations } \\
\text { and are found at low tide marks on sandy } \\
\text { muddy substrates. It is observed to be partly } \\
\text { buried and attached by their tube feet to } \\
\text { buried stones or gravel (Lane, 2008) }\end{array}$ & Unknown & Western Central Pacific: Singapore (Anonymous, 2020b) \\
\hline $\begin{array}{l}\text { Stichopus chloronotus } \\
\text { Brandt, } 1835\end{array}$ & $\begin{array}{l}\text { An inhabitant of coral reefs, in shallow } \\
\text { waters from the intertidal to depths of } 10 \mathrm{~m} \text {. } \\
\text { Found mostly on coarse coral sand and } \\
\text { sheltered habitats with coral rubble. }\end{array}$ & Yes & $\begin{array}{l}\text { Islands of western Indian Ocean, Mascarene Islands, East Africa, Madagascar, } \\
\text { Maldives, Sri Lanka, Bay of Bengal, East Indies, North Australia, the Philippines, China } \\
\text { and southern Japan, most of the islands of the Central Western Pacific but apparently } \\
\text { absent from the Marshall Islands. }\end{array}$ \\
\hline $\begin{array}{l}\text { Stichopus herrmanni } \\
\text { Semper, } 1868\end{array}$ & $\begin{array}{l}\text { Occurs in a wide range of shallow tropical habitats. } \\
\text { In the western central Pacific, It prefers seagrass } \\
\text { beds, rubble and sandy-muddy bottoms between } 0 \\
\text { and } 25 \mathrm{~m} \text {. In the Africa and Indian Ocean region, it } \\
\text { can be found in lagoons, seagrass beds and rubble } \\
\text { over sandy-muddy bottoms between } 0 \text { and } 5 \mathrm{~m} \text {. }\end{array}$ & Yes & $\begin{array}{l}\text { Mascarene Islands, East Africa and Madagascar, Red Sea, southeast Arabia, Gulf of } \\
\text { Aqaba, Persian Gulf, Maldives, Sri Lanka, Bay of Bengal, East Indies, North Australia, } \\
\text { the Philippines, China and southern Japan. It occurs in most countries of the western } \\
\text { Pacific as far east as about Tonga and as far south as Lord Howe Island. }\end{array}$ \\
\hline $\begin{array}{l}\text { Stichopus vastus } \\
\text { Sluiter, } 1887\end{array}$ & $\begin{array}{l}\text { This species is found on inshore reefs edges } \\
\text { on sand, coral rubble or muddy sand in } \\
\text { shallow waters, generally to about } 8 \mathrm{~m} \text { depth. }\end{array}$ & Yes & $\begin{array}{l}\text { Indonesia, the Philippines, Papua New Guinea, Palau Islands, Yap (Federated States of } \\
\text { Micronesia) and northeastern Australia. Although also reported from Uri, Vanuatu, it } \\
\text { does not appear to occur in New Caledonia. }\end{array}$ \\
\hline $\begin{array}{l}\text { Stolus buccalis } \\
\text { (Stimpson, 1855) }\end{array}$ & $\begin{array}{l}\text { depth range } 0-21 \mathrm{~m} \text {. Found concealed under } \\
\text { rock or in narrow crevices (Thandar, 1990). }\end{array}$ & Unknown & $\begin{array}{l}\text { distributed in SE Arabia, Persian Gulf, W India, Pakistan, Ceylon, Bay of Bengal, East } \\
\text { Indies, north Australia, Philippine, China and south Japan (Clark \& Rowe, 1971); } \\
\text { Australia (Rowe \& Gates, 1995). }\end{array}$ \\
\hline $\begin{array}{l}\text { Thelenota ananas } \\
\text { (Jaeger, 1833) }\end{array}$ & $\begin{array}{l}\text { In the western central Pacific, it prefers reef } \\
\text { slopes and passes, hard bottoms with large } \\
\text { coral rubble and coral patches in waters } \\
\text { between } 1 \text { and } 25 \mathrm{~m} \text {. }\end{array}$ & Yes & $\begin{array}{l}\text { Red Sea, Mascarene Islands, Maldives, East Indies, North Australia, the Philippines, } \\
\text { Indonesia, China and southern Japan, and islands of the Central Western Pacific as far } \\
\text { east as French Polynesia. }\end{array}$ \\
\hline $\begin{array}{l}\text { Thelenota anax } \\
\text { Clark, } 1921\end{array}$ & $\begin{array}{l}\text { It primarily inhabits reef slopes and outer } \\
\text { lagoons on sandy bottoms between } 10 \text { and } 30 \\
\mathrm{~m} \text {. It may be found less commonly in } \\
\text { shallower waters to about } 4-5 \mathrm{~m} \text { depth, and } \\
\text { on hard bottoms or on coral rubble }\end{array}$ & Yes & $\begin{array}{l}\text { Tropical Indo-west Pacific. In the tropical Indian Ocean, this species is known from } \\
\text { East Africa, the Comoros and Glorieuses Islands. It is present in much of Southeast } \\
\text { Asia, including Indonesia, the Philippines and the south China Sea. In the tropical } \\
\text { Pacific, from northwestern Australia to Enewetok, Guam, and the Ryukyu Islands } \\
\text { southwards to most of the islands of the Central Western Pacific and as far east as French } \\
\text { Polynesia. }\end{array}$ \\
\hline
\end{tabular}




\section{$\mathrm{Pb}$ in sea cucumbers}

They were determined quite high levels of $\mathrm{Pb}$ in Holothuria leucospilota (23.24 $\pm 0.70 \mathrm{mg} / \mathrm{kg}$ dry wt.), Holothuria tubulosa (18 $\pm 12.9 \mathrm{mg} / \mathrm{kg}$ dry wt.) and Holothuria atra (15.67 mg / kg dry wt.) collected from Qeshm Island Persian Gulf, Calvi Bay Corsica, Terengganu (Mohammadizadeh et al., 2016; Warnau et al., 2006; Ismail et al., 2004). In contrast, low Pb levels or below detection level were found in Holothuria atra and Bohadschia argus ( $<0.3 \mathrm{mg} / \mathrm{kg}$ dry wt.) taken from Guam (Denton et al., 1999), Apostichopus japonicus (0.065 mg / kg wet wt.) taken from China (Jiang et al., 2014), Holothuria atra $(0.09752 \pm 0.07514 \mathrm{mg} / \mathrm{kg}$ dry wt.), Holothoria edulis $(0.0337 \pm 0.1122 \mathrm{mg} / \mathrm{kg}$ dry wt. $)$, Holothuria scabra (0.03471 $\pm 0.04774 \mathrm{mg} / \mathrm{kg}$ dry wt.), Stichopus chloronotus $(0.01620 \pm 0.00271 \mathrm{mg} / \mathrm{kg}$ dry wt.) taken from Sri Lanka (Jinadasa et al., 2014) and Actinopyga mauritiana (ND) taken from Pakistan (Haider et al., 2015).

\section{$\mathrm{Hg}$ in sea cucumbers}

Hg levels in Stichopus herrmanni, Acaudina leucoprocta, Apostichopus japonicus, Actinopyga miliaris, Holothuria arenicola, Stichopus vastus, Ohshimella ehrenbergii, Holothuria atra and Holothuria leueospilota examined by references in Table 2 are low (Ismail et al., 2004; Lin et al., 2018; Jiang et al., 2014; Jinadasa et al., 2014; Ahmed et al., 2018c; Rasyid, 2017; Ahmed et al., 2019) or near the limits of analytical detections (Denton et al., 1999) or non-detectable (Ahmed and Bat, 2020). The highest Hg concentration was found in Stichopus herrmanni species with $3.754 \mathrm{mg} / \mathrm{kg}$ wet wt. from Kayeli Bay, Indonesia (Fretes et al., 2020), followed by Holothuria scabra with a value of $0.44569 \pm 0.19632 \mathrm{mg} / \mathrm{kg}$ dry wt. from Sri Lanka (Jinadasa et al., 2014).

\section{Zn in sea cucumbers}

High Zn levels were found in Holothuria leucospilota (97.27 mg / kg dry wt.) from Hong Kong (Xing and Chia, 1997), Holothuria scabra ( $77 \pm 6 \mathrm{mg} / \mathrm{kg}$ dry wt.) and Thelenota ananas (46 $\pm 5 \mathrm{mg} / \mathrm{kg}$ dry wt.) from Guangzhou China (Wen and Hu, 2010), Holothuria impatiens ( $61 \pm 7.21 \mathrm{mg} / \mathrm{kg}$ dry wt.) and Actinophyga bannwarthi (46.29 $\pm 8.85 \mathrm{mg} / \mathrm{kg}$ dry wt.) from Gulf of Aqaba Jordan (Al-Najjar et al. 2018) and Holothuria leucospilota (46.18 $\pm 1.87 \mathrm{mg} / \mathrm{kg}$ dry wt.) from Persian Gulf (Mohammadizadeh et al., 2016).

\section{Fe in sea cucumbers}

There are excessive differences between Fe amounts in sea cucumber species. Fe levels were lowest in Holothuria scabra $(5.03 \pm 5.35 \mathrm{mg} / \mathrm{kg}$ dry wt.) from Sri Lanka (Jinadasa et al., 2014) and highest in Actinopyga mauritiana (660 $\pm 36 \mathrm{mg} / \mathrm{kg}$ dry wt.) from Guangzhou China (Wen and Hu, 2010).

\section{Mn in sea cucumbers}

Mn amounts in sea cucumber are also very variable. The minimum Mn amount was Actinophyga bannwarthi (0.08 $\pm 0.05 \mathrm{mg} / \mathrm{kg}$ dry wt.), while the maximum value was in Holothuria impatiens $(209.65 \pm 21.53 \mathrm{mg} / \mathrm{kg}$ dry wt.) from Gulf of Aqaba, Jordan (Al-Najjar et al., 2018). It seems interesting that both sea cucumber species were collected from the same region.

\section{Ni in sea cucumbers}

The highest Ni concentration was found in Holothuria tubuosa (24.16 $\pm 2.62 \mathrm{mg} / \mathrm{kg}$ dry wt.) from Dardanelles Strait Turkey (Turk Çulha et al., 2016). Ni levels in the rest of sea cucumber species ranged from $0.19 \pm 0.02$ to $5.1 \pm 1.0 \mathrm{mg} / \mathrm{kg}$ dry wt. (see Table 2).

\section{$\mathrm{Cr}$ in sea cucumbers}

The results of available $\mathrm{Cr}$ data showed that highest level was recorded in Actinopyga mauritiana with $9.6 \pm 0.9 \mathrm{mg}$ / kg dry wt. from Guangzhou China (Wen and Hu, 2010). On the other hand, Cr levels in Actinopyga mauritiana and Holothuria arenicola from Pakistan were found to be below the measurable value (Haider et al., 2015). Similarly, Cr values were found very low in Actinopyga miliaris with $0.00385 \pm 0.00206 \mathrm{mg} / \mathrm{kg}$ dry wt., Bohadschia sp. with $0.00117 \pm 0.00066 \mathrm{mg} / \mathrm{kg}$ dry wt., Bohadschia marmorata with $0.00046 \pm 0.00012 \mathrm{mg} / \mathrm{kg}$ dry wt., Bohadschia similis with $0.00470 \pm 0.00271 \mathrm{mg} /$ $\mathrm{kg}$ dry wt., Holothoria edulis with $0.003 \pm 0.00185 \mathrm{mg} /$ kg dry wt., Holothuria scabra with $0.00059 \pm 0.00022 \mathrm{mg}$ / kg dry wt., Holothuria spinifera with $0.00131 \pm 0.00042$ mg / kg dry wt., Stichopus chloronotus with $0.00099 \pm 0.00018 \mathrm{mg} / \mathrm{kg}$ dry wt. and Thelenota anax with $0.00020 \pm 0.00016 \mathrm{mg} / \mathrm{kg}$ dry wt. from Sri Lanka (Jinadasa et al., 2014).

\section{As in sea cucumbers}

Few studies have focused on accumulation of As in sea cucumber species. As amounts varied considerably between species. Denton et al. (1999) determined As in Bohadschia argus and Holothuria atra from Guam and found very different levels ranged from $<0.01$ to 17.7 and from $<0.01$ to $23.2 \mathrm{mg} / \mathrm{kg}$ dry wt., respectively. This was followed by Apostichopus japonicus from China between $4.26 \pm 0.87$ and $12.39 \pm 0.25 \mathrm{mg} / \mathrm{kg}$ dry wt. (Mohsen et al., 2019).

\section{Co in sea cucumbers}

Co levels have not been studied much, however Co levels in almost all species of echinoderms studied are low, with maximum value $0.00025 \pm 0.00002 \mathrm{mg} / \mathrm{kg}$ dry wt. in Stichopus chloronotus from Sri Lanka coasts (Jinadasa et al., 2014). 
Table 2. Metals in sea cucumber species from seas of the World

\begin{tabular}{|c|c|c|c|c|c|c|c|c|c|c|c|c|c|c|c|}
\hline \multirow{2}{*}{ Species } & \multirow{2}{*}{ Region } & \multirow{2}{*}{$\begin{array}{l}\text { d/ } \\
\text { w }\end{array}$} & \multirow{2}{*}{ Tiss. } & \multicolumn{11}{|c|}{ Metals } & \multirow{2}{*}{ References } \\
\hline & & & & $\mathbf{C d}$ & $\mathbf{C u}$ & $\mathbf{P b}$ & $\mathbf{H g}$ & $\mathbf{Z n}$ & $\mathrm{Fe}$ & Mn & $\mathrm{Ni}$ & $\mathrm{Cr}$ & As & Co & \\
\hline $\begin{array}{c}\text { Acaudina } \\
\text { leucoprocta }\end{array}$ & $\begin{array}{c}\text { Xiangshan, } \\
\text { China } \\
\end{array}$ & d & $\begin{array}{c}\text { Body } \\
\text { wall }\end{array}$ & $0.05 \pm 0.01$ & $2.13 \pm 0.01$ & $1.38 \pm 0.21$ & $0.06 \pm 0.01$ & $9.06 \pm 0.14$ & - & $9.06 \pm 0.14$ & - & $0.33 \pm 0.11$ & $5.64 \pm 0.24$ & - & Lin et al., 2018 \\
\hline $\begin{array}{c}\text { Actinophyga } \\
\text { bannwarthi }\end{array}$ & $\begin{array}{l}\text { Gulf of } \\
\text { Aqaba, } \\
\text { Jordan }\end{array}$ & d & $\begin{array}{l}\text { Body } \\
\text { wall }\end{array}$ & $0.13 \pm 0.07$ & $7.37 \pm 3.54$ & $1.43 \pm 1.43$ & - & $\begin{array}{c}46.29 \pm 8.8 \\
5\end{array}$ & $\begin{array}{c}148.7 \pm 32 . \\
18\end{array}$ & $0.08 \pm 0.05$ & $1.43 \pm 0.39$ & - & - & - & Al-Najjar et al., 2018 \\
\hline $\begin{array}{c}\text { Actinopyga } \\
\text { caerulea }\end{array}$ & $\begin{array}{l}\text { Guangzhou, } \\
\text { China }\end{array}$ & d & - & - & $4 \pm 1$ & - & - & $20 \pm 1$ & $41 \pm 6$ & $1.1 \pm 0.1$ & $0.5 \pm 0.1$ & $1.3 \pm 0.1$ & - & - & Wen and $\mathrm{Hu}, 2010$ \\
\hline $\begin{array}{c}\text { Actinopyga } \\
\text { lecanora }\end{array}$ & $\begin{array}{c}\text { Sabah, } \\
\text { Malaysia } \\
\end{array}$ & - & - & 0.02 & 1.13 & 0.16 & - & 9.67 & - & 2.46 & - & 2.46 & 0.16 & - & Hashmi et al., 2014 \\
\hline $\begin{array}{l}\text { Actinopyga } \\
\text { mauritiana }\end{array}$ & Pakistan & d & $\begin{array}{c}\text { Body } \\
\text { wall }\end{array}$ & ND & $5.11 \pm 0.1$ & ND & - & $5.23 \pm 0.04$ & & $5.85 \pm 0.07$ & $0.25 \pm 0.03$ & ND & - & - & Haider et al., 2015 \\
\hline $\begin{array}{l}\text { Actinopyga } \\
\text { mauritiana }\end{array}$ & $\begin{array}{l}\text { Guangzhou, } \\
\text { China }\end{array}$ & d & - & - & $14 \pm 2$ & - & - & $57 \pm 3$ & $660 \pm 36$ & $9.2 \pm 0.5$ & $4.2 \pm 0.9$ & $9.6 \pm 0.9$ & - & - & Wen and $\mathrm{Hu}, 2010$ \\
\hline $\begin{array}{c}\text { Actinopyga } \\
\text { miliaris }\end{array}$ & Sri Lanka & d & $\begin{array}{c}\text { Body } \\
\text { wall }\end{array}$ & $\begin{array}{c}0.05266 \pm \\
0.01361 \\
\end{array}$ & $9.18 \pm 2.14$ & $\begin{array}{c}2.28705 \pm \\
0.91715 \\
\end{array}$ & $\begin{array}{c}0.07284 \pm \\
0.01208 \\
\end{array}$ & $\begin{array}{c}12.11 \pm 2.9 \\
0 \\
\end{array}$ & $\begin{array}{c}43.58 \pm 12 . \\
15 \\
\end{array}$ & - & - & $\begin{array}{c}0.00385 \pm \\
0.00206 \\
\end{array}$ & & $\begin{array}{c}0.00008 \pm \\
0.00003 \\
\end{array}$ & Jinadasa et al., 2014 \\
\hline $\begin{array}{l}\text { Apostichopus } \\
\text { japonicus }\end{array}$ & China & d & $\begin{array}{l}\text { Body } \\
\text { wall }\end{array}$ & $\begin{array}{l}0.31 \pm 0.03 \\
0.85 \pm 0.02\end{array}$ & $\begin{array}{l}1.55 \pm 0.16 \\
8.21 \pm 0.19\end{array}$ & $\begin{array}{l}1.05 \pm 0.13 \\
4.25 \pm 0.23\end{array}$ & 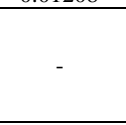 & $\begin{array}{c}20.30 \pm 1.0 \\
2 \\
36.21 \pm 0.1 \\
5 \\
\end{array}$ & & $\begin{array}{c}16.37 \pm 0.4 \\
2 \\
58.91 \pm 2.8 \\
3 \\
\end{array}$ & $\begin{array}{l}1.18 \pm 0.11 \\
1.77 \pm 0.10\end{array}$ & $\begin{array}{l}2.29 \pm 0.23 \\
4.61 \pm 0.18\end{array}$ & $\begin{array}{c}4.26 \pm 0.87 \\
12.39 \pm 0.2 \\
5\end{array}$ & 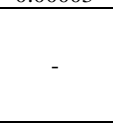 & Mohsen et al., 2019 \\
\hline $\begin{array}{c}\text { Apostichopus } \\
\text { japonicus } \\
\text { (Juvenile) }\end{array}$ & China & w & - & 0.161 & 0.179 & 0.065 & 0.034 & 2.634 & - & - & - & 0.108 & 0.372 & - & Jiang et al., 2014 \\
\hline Bohadschia sp. & Sri Lanka & d & $\begin{array}{c}\text { Body } \\
\text { wall }\end{array}$ & $\begin{array}{c}0.12893 \pm \\
0.04486 \\
\end{array}$ & $4.30 \pm 3.66$ & $\begin{array}{c}0.49164 \pm \\
0.43710 \\
\end{array}$ & $\begin{array}{c}0.16633 \pm \\
0.05251 \\
\end{array}$ & $\begin{array}{c}12.68 \pm 5.1 \\
8 \\
\end{array}$ & $\begin{array}{c}55.46 \pm 59 . \\
51 \\
\end{array}$ & - & - & $\begin{array}{c}0.00117 \pm \\
0.00066 \\
\end{array}$ & - & $\begin{array}{c}0.00016 \pm \\
0.00009 \\
\end{array}$ & Jinadasa et al., 2014 \\
\hline $\begin{array}{c}\text { Bohadschia } \\
\text { argus }\end{array}$ & $\begin{array}{l}\text { Guangzhou, } \\
\text { China }\end{array}$ & d & - & - & $18 \pm 3$ & - & - & $100 \pm 19$ & $330 \pm 41$ & $3.7 \pm 0.1$ & $5.1 \pm 1.0$ & $4.9 \pm 0.6$ & - & - & Wen and Hu, 2010 \\
\hline $\begin{array}{l}\text { Bohadschia } \\
\text { argus }\end{array}$ & Guam & d & $\begin{array}{l}\text { body wall } \\
\text { muscle } \\
\text { tissue }\end{array}$ & 0.1 & $0.6-2.3$ & $<0.3-<0.6$ & $\begin{array}{l}0.000001- \\
0.000007\end{array}$ & $8.3-18.0$ & - & - & $0.3-1.4$ & $<0.1-0.4$ & $\begin{array}{l}<0.01- \\
17.7\end{array}$ & - & Denton et al., 1999 \\
\hline $\begin{array}{l}\text { Bohadschia } \\
\text { marmorata }\end{array}$ & Sri Lanka & d & $\begin{array}{c}\text { Body } \\
\text { wall }\end{array}$ & $\begin{array}{c}0.137 \pm 0.0 \\
2932\end{array}$ & $2.81 \pm 1.02$ & $\begin{array}{c}0.22702 \pm \\
0.19389 \\
\end{array}$ & $\begin{array}{c}0.11622 \pm \\
0.12974 \\
\end{array}$ & $\begin{array}{c}16.06 \pm 12 . \\
06\end{array}$ & $\begin{array}{c}23.06 \pm 8.2 \\
3\end{array}$ & - & - & $\begin{array}{c}0.00046 \pm \\
0.00012\end{array}$ & - & $\begin{array}{c}0.00007 \pm \\
0.00003\end{array}$ & Jinadasa et al., 2014 \\
\hline $\begin{array}{c}\text { Bohadschia } \\
\text { similis }\end{array}$ & Sri Lanka & d & $\begin{array}{c}\text { Body } \\
\text { wall }\end{array}$ & $\begin{array}{c}0.05497 \pm \\
0.03079 \\
\end{array}$ & $5.70 \pm 0.67$ & $\begin{array}{c}0.45053 \pm \\
0.29131 \\
\end{array}$ & $\begin{array}{c}0.12703 \pm \\
0.04146 \\
\end{array}$ & $\begin{array}{c}16.22 \pm 6.2 \\
6 \\
\end{array}$ & $\begin{array}{c}56.68 \pm 17 . \\
77 \\
\end{array}$ & - & - & $\begin{array}{c}0.00470 \pm \\
0.00271 \\
\end{array}$ & - & $\begin{array}{c}0.00009 \pm \\
0.00002 \\
\end{array}$ & Jinadasa et al., 2014 \\
\hline $\begin{array}{c}\text { Bohadachio } \\
\text { vitiens }\end{array}$ & $\begin{array}{c}\text { Sabah, } \\
\text { Malaysia } \\
\end{array}$ & - & - & 0.03 & 0.87 & 0.12 & - & 7.83 & - & 2.27 & - & 1.35 & 0.25 & - & Hashmi et al., 2014 \\
\hline $\begin{array}{c}\text { Holothuria } \\
\text { arenicola }\end{array}$ & $\begin{array}{c}\text { Northern } \\
\text { Arabian Sea }\end{array}$ & d & $\begin{array}{l}\text { Body } \\
\text { wall }\end{array}$ & $0.12-1.42$ & $0.43-2.23$ & $0.92-2.33$ & - & $11-28$ & $47-33$ & $2.45-5.32$ & - & - & - & - & Ahmed et al., 2017 \\
\hline $\begin{array}{c}\text { Holothuria } \\
\text { arenicola }\end{array}$ & $\begin{array}{l}\text { Karachi, } \\
\text { Pakistan } \\
\end{array}$ & d & muscle & - & - & - & 0.018 & - & - & - & - & - & - & - & Ahmed et al., 2018c \\
\hline $\begin{array}{l}\text { Holothuria } \\
\text { arenicola }\end{array}$ & Pakistan & d & $\begin{array}{l}\text { Body } \\
\text { wall }\end{array}$ & ND & $\begin{array}{c}0.95 \pm 0.01 \\
*\end{array}$ & ND & - & $\begin{array}{l}4.28 \pm 0.06 \\
*\end{array}$ & - & $\begin{array}{c}5.23 \pm 0.04 \\
*\end{array}$ & $\begin{array}{c}0.19 \pm 0.02 \\
*\end{array}$ & ND & - & - & $\begin{array}{l}\text { Haider et al., 2015* } \\
\mathrm{Mg} / 100 \mathrm{~g}\end{array}$ \\
\hline $\begin{array}{l}\text { Holothuria } \\
\text { atra }\end{array}$ & Guam & d & $\begin{array}{c}\text { body wall } \\
\text { muscle } \\
\text { tissue }\end{array}$ & $<0.1-0.1$ & $0.7-2.5$ & $<0.3-<0.6$ & $\begin{array}{l}0.000007- \\
0.000022\end{array}$ & $12.6-21.2$ & - & - & $<0.2-<0.3$ & $<0.1-0.3$ & $\begin{array}{l}<0.01- \\
23.2\end{array}$ & - & Denton et al., 1999 \\
\hline $\begin{array}{l}\text { Holothuria } \\
\text { atra }\end{array}$ & $\begin{array}{c}\text { Pulau } \\
\text { Pangkor, } \\
\text { Perak and } \\
\text { Pulau Kapas, } \\
\text { Terengganu } \\
\end{array}$ & d & body wall & $8.0-33.03$ & $\begin{array}{l}31.32- \\
41.13\end{array}$ & $\begin{array}{l}10.32- \\
15.67\end{array}$ & $0.08-0.17$ & $\begin{array}{l}30.38- \\
51.67\end{array}$ & - & - & - & - & - & - & Ismail et al., 2004 \\
\hline $\begin{array}{c}\text { Holothuria } \\
\text { atra }\end{array}$ & $\begin{array}{c}\text { Northern } \\
\text { Arabian Sea } \\
\end{array}$ & d & $\begin{array}{c}\text { Body } \\
\text { wall }\end{array}$ & $0.52-1.11$ & $2.03-3.89$ & $0.69-1.23$ & - & $18-24$ & $19-26$ & $1.09-2.49$ & - & - & - & - & Ahmed et al., 2017 \\
\hline
\end{tabular}


Bat et al., / IJEGEO 7(3): 252-264 (2020)

\begin{tabular}{|c|c|c|c|c|c|c|c|c|c|c|c|c|c|c|c|}
\hline $\begin{array}{c}\text { Holothuria } \\
\text { atra }\end{array}$ & Sri Lanka & d & $\begin{array}{c}\text { Body } \\
\text { wall }\end{array}$ & $\begin{array}{c}0.07252 \pm \\
0.00888 \\
\end{array}$ & $3.18 \pm 1.02$ & $\begin{array}{c}0.09752 \pm \\
0.07514 \\
\end{array}$ & $\begin{array}{c}0.03112 \pm \\
0.01282 \\
\end{array}$ & $\begin{array}{c}24.38 \pm 3.9 \\
6 \\
\end{array}$ & $\begin{array}{c}11.72 \pm 12 \\
11\end{array}$ & - & - & $<0.04$ & - & $\begin{array}{c}0.00009 \pm \\
0.00006 \\
\end{array}$ & Jinadasa et al., 2014 \\
\hline $\begin{array}{c}\text { Holothuria } \\
\text { atra }\end{array}$ & $\begin{array}{l}\text { Karachi, } \\
\text { Pakistan }\end{array}$ & d & muscle & - & - & - & 0.036 & - & - & - & - & - & - & - & Ahmed et al., 2018c \\
\hline $\begin{array}{l}\text { Holothuria } \\
\text { cinerascens }\end{array}$ & $\begin{array}{c}\text { Northern } \\
\text { Arabian Sea } \\
\end{array}$ & d & $\begin{array}{l}\begin{array}{c}\text { Body } \\
\text { wall }\end{array} \\
\end{array}$ & 2.67 & 8.93 & 2.12 & - & 37 & 52 & 4.64 & - & - & - & - & Ahmed et al., 2017 \\
\hline $\begin{array}{c}\text { Holothoria } \\
\text { edulis }\end{array}$ & $\begin{array}{c}\text { Sabah, } \\
\text { Malaysia } \\
\end{array}$ & - & - & 0.12 & 1.12 & 0.14 & - & 7.26 & - & 1.25 & - & 1.14 & 0.54 & - & Hashmi et al., 2014 \\
\hline $\begin{array}{c}\text { Holothoria } \\
\text { edulis }\end{array}$ & Sri Lanka & d & $\begin{array}{l}\text { Body } \\
\text { wall }\end{array}$ & $\begin{array}{c}0.11447 \pm \\
0.07601 \\
\end{array}$ & $1.84 \pm 3.71$ & $\begin{array}{c}0.0337 \pm 0 . \\
1122\end{array}$ & $\begin{array}{c}.02463 \pm \\
0.01676 \\
\end{array}$ & $\begin{array}{c}20.95 \pm 6.7 \\
5\end{array}$ & $\begin{array}{c}39.82 \pm 23 . \\
17\end{array}$ & - & - & $\begin{array}{c}0.003 \pm 0.0 \\
0185\end{array}$ & - & $\begin{array}{c}0.00013 \pm \\
0.0001\end{array}$ & Jinadasa et al., 2014 \\
\hline $\begin{array}{l}\text { Holothuria } \\
\text { fuscogilva }\end{array}$ & $\begin{array}{l}\text { Guangzhou, } \\
\text { China }\end{array}$ & d & - & - & $57 \pm 5$ & - & - & $11 \pm 2$ & $250 \pm 36$ & $9.4 \pm 0.3$ & $1.5 \pm 0.5$ & $1.3 \pm 0.1$ & - & - & Wen and Hu, 2010 \\
\hline $\begin{array}{c}\text { Holothuria } \\
\text { fuscopunctata }\end{array}$ & $\begin{array}{c}\text { Guangzhou, } \\
\text { China }\end{array}$ & d & - & - & $74 \pm 9$ & - & - & $25 \pm 2$ & $100 \pm 20$ & $12 \pm 0.6$ & $3.0 \pm 0.7$ & $5.5 \pm 0.5$ & - & - & Wen and Hu, 2010 \\
\hline $\begin{array}{l}\text { Holothuria } \\
\text { impatiens }\end{array}$ & $\begin{array}{l}\text { Gulf of } \\
\text { Aqaba, } \\
\text { Jordan } \\
\end{array}$ & d & $\begin{array}{l}\text { Body } \\
\text { wall }\end{array}$ & $0.12 \pm 0.06$ & $1.06 \pm 0.49$ & $8.35 \pm 1.14$ & - & $61 \pm 7.21$ & $\begin{array}{c}107.9 \pm 17 \\
3\end{array}$ & $\begin{array}{c}209.65 \pm 2 \\
1.53\end{array}$ & $0.42 \pm 0.18$ & - & - & - & Al-Najjar et al., 2018 \\
\hline $\begin{array}{l}\text { Holothuria } \\
\text { leucospilota }\end{array}$ & Hong Kong & $\mathrm{d}$ & $\begin{array}{c}\text { muscle } \\
\text { digestive } \\
\text { tract } \\
\text { body wall } \\
\end{array}$ & - & $\begin{array}{l}0.25 \\
5.53 \\
2.11\end{array}$ & - & - & $\begin{array}{c}97.27 \\
42.96 \\
8.14\end{array}$ & - & - & - & - & - & - & Xing and Chia, 1997 \\
\hline $\begin{array}{c}\text { Holothuria } \\
\text { leucospilota }\end{array}$ & $\begin{array}{c}\text { Northern } \\
\text { Arabian Sea }\end{array}$ & d & $\begin{array}{c}\text { Body } \\
\text { wall }\end{array}$ & 1.02 & 8.64 & 2.19 & - & 46 & 73 & 7.12 & - & - & - & - & Ahmed et al., 2017 \\
\hline $\begin{array}{l}\text { Holothuria } \\
\text { leucospilota }\end{array}$ & $\begin{array}{c}\text { Qeshm } \\
\text { Island, } \\
\text { Persian Gulf }\end{array}$ & d & $\begin{array}{l}\text { Body } \\
\text { wall }\end{array}$ & $\begin{array}{l}0.16 \pm 0.01 \\
0.45 \pm 0.05\end{array}$ & $\begin{array}{c}64.81 \pm 1.6 \\
4 \\
97.69 \pm 0.6 \\
1\end{array}$ & $\begin{array}{c}19.09 \pm 0.6 \\
8 \\
23.24 \pm 0.7 \\
0\end{array}$ & - & $\begin{array}{c}40.00 \pm 1.2 \\
6 \\
46.18 \pm 1.8 \\
7\end{array}$ & - & - & - & - & - & - & $\begin{array}{l}\text { Mohammadizadeh et } \\
\text { al., } 2016\end{array}$ \\
\hline $\begin{array}{l}\text { Holothuria } \\
\text { leueospilota } \\
\end{array}$ & $\begin{array}{c}\text { Sabah, } \\
\text { Malaysia } \\
\end{array}$ & - & - & 0.05 & 0.87 & 0.3 & - & 16.27 & - & 2.24 & - & 1.55 & 2.43 & - & Hashmi et al., 2014 \\
\hline $\begin{array}{l}\text { Holothuria } \\
\text { leueospilota }\end{array}$ & $\begin{array}{l}\text { Karachi, } \\
\text { Pakistan }\end{array}$ & d & $\begin{array}{l}\text { muscle } \\
\text { and skin }\end{array}$ & - & - & - & $\begin{array}{c}\text { LOD- } \\
0.0034 \\
\text { LOD- } \\
0.0046 \\
\end{array}$ & - & - & - & - & - & - & - & Ahmed and Bat, 2020 \\
\hline $\begin{array}{l}\text { Holothuria } \\
\text { mexicana }\end{array}$ & $\begin{array}{l}\text { Guangzhou, } \\
\text { China }\end{array}$ & d & - & - & $30 \pm 2$ & - & - & $16 \pm 2$ & $190 \pm 29$ & $1.6 \pm 0.2$ & $1.1 \pm 0.3$ & $2.2 \pm 0.2$ & - & - & Wen and $\mathrm{Hu}, 2010$ \\
\hline $\begin{array}{c}\text { Holothuria } \\
\text { pardalis }\end{array}$ & $\begin{array}{l}\text { Karachi, } \\
\text { Pakistan } \\
\end{array}$ & $\mathrm{d}$ & muscle & - & - & - & 0.026 & - & - & - & - & - & - & - & Ahmed et al., $2018 \mathrm{c}$ \\
\hline $\begin{array}{c}\text { Holothuria } \\
\text { scabra }\end{array}$ & $\begin{array}{l}\text { Guangzhou, } \\
\text { China }\end{array}$ & d & - & - & $18 \pm 3$ & - & - & $77 \pm 6$ & $130 \pm 19$ & $1.4 \pm 0.1$ & $0.6 \pm 0.2$ & $1.1 \pm 0.1$ & - & - & Wen and Hu, 2010 \\
\hline $\begin{array}{l}\text { Holothuria } \\
\text { scabra }\end{array}$ & $\begin{array}{c}\text { Qeshm } \\
\text { Island, } \\
\text { Persian Gulf }\end{array}$ & d & $\begin{array}{l}\text { Body } \\
\text { wall }\end{array}$ & $\begin{array}{l}0.13 \pm 0.02 \\
0.17 \pm 0.01\end{array}$ & $\begin{array}{c}44.48 \pm 0.8 \\
9 \\
81.16 \pm 1.0 \\
5 \\
\end{array}$ & $\begin{array}{l}1.52 \pm 0.17 \\
2.55 \pm 0.09\end{array}$ & - & $\begin{array}{c}19.30 \pm 0.9 \\
3 \\
29.12 \pm 0.8 \\
8 \\
\end{array}$ & - & - & - & - & - & - & $\begin{array}{l}\text { Mohammadizadeh et } \\
\text { al., } 2016\end{array}$ \\
\hline $\begin{array}{c}\text { Holothuria } \\
\text { scabra }\end{array}$ & Sri Lanka & d & $\begin{array}{l}\begin{array}{c}\text { Body } \\
\text { wall }\end{array} \\
\end{array}$ & $\begin{array}{c}0.04162 \pm \\
0.00695 \\
\end{array}$ & $3.45 \pm 1.0$ & $\begin{array}{c}0.03471 \pm \\
0.04774 \\
\end{array}$ & $\begin{array}{c}0.44569 \pm \\
0.19632 \\
\end{array}$ & $3.68 \pm 0.45$ & $5.03 \pm 5.35$ & - & - & $\begin{array}{c}0.00059 \pm \\
0.00022 \\
\end{array}$ & - & $\begin{array}{c}0.00012 \pm \\
0.00003 \\
\end{array}$ & Jinadasa et al., 2014 \\
\hline $\begin{array}{c}\begin{array}{c}\text { Holothuria } \\
\text { spinifera }\end{array} \\
\end{array}$ & Sri Lanka & d & $\begin{array}{c}\begin{array}{c}\text { Body } \\
\text { wall }\end{array} \\
\end{array}$ & $\begin{array}{c}0.048 .3 \pm 0 \\
.01242 \\
\end{array}$ & $4.42 \pm 3.12$ & $\begin{array}{c}0.20456 \pm \\
0.48047 \\
\end{array}$ & $\begin{array}{c}0.1337 \pm 0 . \\
09633 \\
\end{array}$ & $8.77 \pm 3.07$ & $\begin{array}{c}20.09 \pm 12 . \\
79 \\
\end{array}$ & - & - & $\begin{array}{c}0.00131 \pm \\
0.00042 \\
\end{array}$ & - & $\begin{array}{c}0.00008 \pm \\
0.00006 \\
\end{array}$ & Jinadasa et al., 2014 \\
\hline $\begin{array}{l}\text { Holothuria } \\
\text { tubuosa }\end{array}$ & $\begin{array}{l}\text { Dardanelles } \\
\text { Strait, Turkey }\end{array}$ & d & $\begin{array}{l}\text { Body } \\
\text { wall }\end{array}$ & $\begin{array}{l}0.09 \pm 0.01 \\
0.63 \pm 0.23\end{array}$ & $\begin{array}{c}\text { ND- } \\
6.60 \pm 0.12\end{array}$ & $\begin{array}{l}0.71 \pm 0.03 \\
5.34 \pm 0.10\end{array}$ & - & $\begin{array}{c}12.40 \pm 1.0 \\
0 \\
21.27 \pm 2.0 \\
4 \\
\end{array}$ & $\begin{array}{c}50.86 \pm 6.8 \\
0 \\
117.63 \pm 3 . \\
29 \\
\end{array}$ & - & $\begin{array}{c}8.31 \pm 0.36 \\
24.16 \pm 2.6 \\
2\end{array}$ & - & - & - & Turk Çulha et al., 2016 \\
\hline $\begin{array}{c}\text { Holothuria } \\
\text { tubulosa }\end{array}$ & $\begin{array}{c}\text { Calvi Bay, } \\
\text { Corsica }\end{array}$ & d & $\begin{array}{c}\text { Body } \\
\text { wall }\end{array}$ & $\begin{array}{l}0.38 \pm 0.16 \\
2.84 \pm 1.25 \\
\end{array}$ & $\begin{array}{l}0.76 \pm 0.16 \\
1.48 \pm 0.24 \\
\end{array}$ & $\begin{array}{c}1.62 \pm 0.09 \\
18 \pm 12.9 \\
\end{array}$ & - & $\begin{array}{l}10.1 \pm 4.14 \\
15.5 \pm 4.52 \\
\end{array}$ & $\begin{array}{c}12.5 \pm 13 \\
216 \pm 194 \\
\end{array}$ & - & - & - & - & - & Warnau et al., 2006 \\
\hline $\begin{array}{l}\text { Holothuria } \\
\text { tubulosa }\end{array}$ & $\begin{array}{l}\text { Ischia Island, } \\
\text { Italys:spe }\end{array}$ & d & $\begin{array}{l}\text { Body } \\
\text { wall }\end{array}$ & $\begin{array}{c}0.50 \pm 0.27 \\
2.28 \pm \\
1.63 \\
\end{array}$ & $\begin{array}{l}1.06 \pm 0.27 \\
5.78 \pm 3.73 \\
\end{array}$ & $\begin{array}{c}1.94 \pm 0.12 \\
6.71 \pm \\
3.75 \\
\end{array}$ & - & $\begin{array}{c}8.87 \pm 3.71 \\
26.0 \pm \\
7.16 \\
\end{array}$ & $\begin{array}{l}18.5 \pm 17 \\
191 \pm 187 \\
\end{array}$ & - & - & - & - & - & Warnau et al., 2006 \\
\hline
\end{tabular}


Bat et al., / IJEGEO 7(3): 252-264 (2020)

\begin{tabular}{|c|c|c|c|c|c|c|c|c|c|c|c|c|c|c|c|}
\hline $\begin{array}{c}\text { Holothuria } \\
\text { tubulosa }\end{array}$ & $\begin{array}{c}\text { Marseille, } \\
\text { France }\end{array}$ & d & $\begin{array}{c}\text { Body } \\
\text { wall }\end{array}$ & $\begin{array}{l}0.44 \pm 0.18 \\
1.85 \pm 0.65\end{array}$ & $\begin{array}{c}1.12 \pm \\
0.232 .28 \\
\pm 0.40 \\
\end{array}$ & $\begin{array}{c}1.23 \pm 0.84 \\
4.69 \pm \\
4.80 \\
\end{array}$ & - & $\begin{array}{c}14.9 \pm 2.24 \\
21.0 \pm \\
5.36 \\
\end{array}$ & $\begin{array}{c}18 \pm 17 \\
106 \pm 128\end{array}$ & - & - & - & - & - & Warnau et al., 2006 \\
\hline $\begin{array}{c}\text { Holothuria } \\
\text { verrucosa }\end{array}$ & $\begin{array}{c}\text { Northern } \\
\text { Arabian Sea }\end{array}$ & d & $\begin{array}{c}\text { Body } \\
\text { wall }\end{array}$ & $0.76-1.76$ & $1.98-3.76$ & $0.52-1.03$ & - & $12-30$ & $23-29$ & $0.76-2.47$ & - & - & - & - & Ahmed et al., 2017 \\
\hline $\begin{array}{c}\text { Holothuria } \\
\text { verrucosa }\end{array}$ & $\begin{array}{l}\text { Karachi, } \\
\text { Pakistan }\end{array}$ & d & muscle & - & - & - & 0.024 & - & - & - & - & - & - & - & Ahmed et al., 2018c \\
\hline $\begin{array}{c}\text { Ohsimella } \\
\text { ehrenbergii }\end{array}$ & $\begin{array}{c}\text { Northern } \\
\text { Arabian Sea }\end{array}$ & $\mathrm{d}$ & $\begin{array}{l}\text { Body } \\
\text { wall }\end{array}$ & $0.31-0.52$ & $2.23-3.98$ & $2.54-3.02$ & - & 24-32 & $32-34$ & $2.11-3.91$ & - & - & - & - & Ahmed et al., 2017 \\
\hline $\begin{array}{l}\text { Ohshimella } \\
\text { ehrenbergii }\end{array}$ & $\begin{array}{l}\text { Karachi, } \\
\text { Pakistan }\end{array}$ & d & $\begin{array}{l}\text { edible } \\
\text { tissues }\end{array}$ & - & - & - & 0.0176 & - & - & - & - & - & - & - & Ahmed et al., 2019 \\
\hline $\begin{array}{c}\text { Phyllophogius } \\
\text { spiculata }\end{array}$ & $\begin{array}{c}\text { Sabah, } \\
\text { Malaysia }\end{array}$ & - & - & 0.05 & 0.75 & 0.13 & - & 9.33 & - & 32.67 & - & 2.16 & 0.3 & - & Hashmi et al., 2014 \\
\hline $\begin{array}{c}\text { Stichopus } \\
\text { chloronotus } \\
\end{array}$ & $\begin{array}{l}\text { Guangzhou, } \\
\text { China }\end{array}$ & d & - & - & $3 \pm 1$ & - & - & $16 \pm 2$ & $80 \pm 23$ & $2.2 \pm 0.2$ & $0.3 \pm 0.1$ & $1.5 \pm 0.1$ & - & - & Wen and $\mathrm{Hu}, 2010$ \\
\hline $\begin{array}{c}\text { Stichopus } \\
\text { chloronotus }\end{array}$ & Sri Lanka & d & $\begin{array}{l}\text { Body } \\
\text { wall }\end{array}$ & $\begin{array}{c}0.08611 \pm \\
0.02537\end{array}$ & $7.25 \pm 8.49$ & $\begin{array}{c}0.01620 \pm \\
0.00271\end{array}$ & $\begin{array}{c}0.24328 \pm \\
0.05932 \\
\end{array}$ & $\begin{array}{c}16.20 \pm 2.7 \\
1\end{array}$ & $\begin{array}{c}39.51 \pm 8.8 \\
4\end{array}$ & - & - & $\begin{array}{c}0.00099 \pm \\
0.00018\end{array}$ & - & $\begin{array}{c}0.00025 \pm \\
0.00002\end{array}$ & Jinadasa et al., 2014 \\
\hline $\begin{array}{l}\text { Stichopus } \\
\text { herrmanni }\end{array}$ & $\begin{array}{c}\text { Pulau } \\
\text { Pangkor, } \\
\text { Perak and } \\
\text { Pulau Kapas, } \\
\text { Terengganu } \\
\end{array}$ & d & body wall & $\begin{array}{l}10.48- \\
12.09\end{array}$ & $\begin{array}{l}29.45- \\
38.87\end{array}$ & $\begin{array}{l}9.87- \\
15.77\end{array}$ & $0.09-0.10$ & $\begin{array}{l}43.54- \\
59.13\end{array}$ & - & - & - & - & - & - & Ismail et al., 2004 \\
\hline $\begin{array}{c}\text { Stichopus } \\
\text { herrmanni }\end{array}$ & $\begin{array}{c}\text { Guangzhou, } \\
\text { China }\end{array}$ & d & - & - & $3 \pm 1$ & - & - & $33 \pm 3$ & $94 \pm 27$ & $9.1 \pm 0.4$ & $0.3 \pm 0.1$ & $1.6 \pm 0.2$ & - & - & Wen and $\mathrm{Hu}, 2010$ \\
\hline $\begin{array}{c}\text { Stichopus } \\
\text { herrmanni }\end{array}$ & $\begin{array}{c}\text { Kayeli Bay, } \\
\text { Indonesia }\end{array}$ & $\mathrm{w}$ & meat & - & - & - & 3.754 & - & 14.6 & - & - & - & - & - & Fretes et al., 2020 \\
\hline $\begin{array}{c}\text { Stichopus } \\
\text { vastus }\end{array}$ & Indonesia & $\mathrm{d}$ & - & $<1.0$ & - & $<1.5$ & $<1.0$ & - & 520.8 & - & - & - & $<1.0$ & - & Rasyid, 2017 \\
\hline $\begin{array}{c}\text { Stichopus } \\
\text { vastus }\end{array}$ & $\begin{array}{c}\text { Sabah, } \\
\text { Malaysia }\end{array}$ & - & - & 0.04 & 0.76 & 0.18 & - & 28.37 & - & 4.77 & - & 2.86 & 0.54 & - & Hashmi et al., 2014 \\
\hline Stolus buccalis & $\begin{array}{l}\text { Karachi, } \\
\text { Pakistan } \\
\end{array}$ & d & $\begin{array}{l}\text { edible } \\
\text { tissues } \\
\end{array}$ & - & - & - & 0.0155 & - & - & - & - & - & - & - & Ahmed et al, 2019 \\
\hline Stolus buccalis & $\begin{array}{c}\text { Northern } \\
\text { Arabian Sea }\end{array}$ & d & $\begin{array}{c}\text { Body } \\
\text { wall }\end{array}$ & 0.11 & 2.46 & 0.82 & - & 19 & 14 & 3.02 & - & - & - & - & Ahmed et al., 2017 \\
\hline $\begin{array}{c}\text { Thelenota } \\
\text { ananas }\end{array}$ & $\begin{array}{l}\text { Guangzhou, } \\
\text { China }\end{array}$ & $\mathrm{d}$ & - & - & $33 \pm 2$ & - & - & $46 \pm 5$ & $210 \pm 39$ & $16 \pm 1.6$ & $2.5 \pm 0.6$ & $2.7 \pm 0.3$ & - & - & Wen and $\mathrm{Hu}, 2010$ \\
\hline $\begin{array}{c}\text { Thelenota } \\
\text { ananas }\end{array}$ & $\begin{array}{c}\text { Sabah, } \\
\text { Malaysia }\end{array}$ & - & - & 2.43 & 1.34 & 0.24 & - & 15.22 & - & 5.65 & - & 3.33 & 0.42 & - & Hashmi et al., 2014 \\
\hline $\begin{array}{c}\text { Thelenota } \\
\text { anax }\end{array}$ & $\begin{array}{c}\text { Sabah, } \\
\text { Malaysia }\end{array}$ & - & - & 0.04 & 0.95 & 0.19 & - & 9.98 & - & 4.04 & & 1.46 & 0.23 & - & Hashmi et al., 2014 \\
\hline $\begin{array}{c}\text { Thelenota } \\
\text { anax }\end{array}$ & $\begin{array}{l}\text { Guangzhou, } \\
\text { China }\end{array}$ & d & - & - & $4 \pm 1$ & - & - & $28 \pm 2$ & $200 \pm 30$ & $10 \pm 0.9$ & $0.7 \pm 0.2$ & $1.5 \pm 0.1$ & - & - & Wen and Hu., 2010 \\
\hline $\begin{array}{l}\text { Thelenota } \\
\text { anax }\end{array}$ & Sri Lanka & d & $\begin{array}{l}\text { Body } \\
\text { wall }\end{array}$ & $\begin{array}{c}0.08451 \pm \\
0.02241\end{array}$ & $2.92 \pm 0.82$ & $\begin{array}{c}0.29757 \pm \\
0.47955\end{array}$ & $\begin{array}{c}0.02867 \pm \\
0.00599\end{array}$ & $\begin{array}{c}22.81 \pm 7.5 \\
1\end{array}$ & $\begin{array}{c}53.82 \pm 30 \\
98\end{array}$ & - & - & $\begin{array}{c}0.00020 \pm \\
0.00016\end{array}$ & - & $\begin{array}{c}0.00019 \pm \\
0.00003\end{array}$ & Jinadasa et al., 2014 \\
\hline
\end{tabular}




\section{Discussion}

Ismail et al. (2004) measured $\mathrm{Cd}, \mathrm{Pb}, \mathrm{Zn}, \mathrm{Cu}$ and $\mathrm{Hg}$ levels in the body walls of Stichopus hermanni and Holothuria atra from Pulau Pangkor, Perak and Pulau Kapas, Terengganu. $\mathrm{Pb}$ amounts in the body walls of both Stichopus hermanni and Holothuria atra were quite larger than the permissible levels for human consumption (Ismail et al., 2004). Cd levels in both sea cucumbers seem too high for human consumption.

Mohammadizadeh et al. (2016) found that $\mathrm{Cu}$ and $\mathrm{Zn}$ amounts in Holothuria leucospilota and Holothuria scabra from the northern part of Qeshm Island, Persian Gulf were below permissible limits, but $\mathrm{Cd}$ and $\mathrm{Pb}$ amounts were much higher than the permissible limits for human consumption. Similarly, $\mathrm{Pb}$ and As amounts in Acaudina leucoprocta from the East China Sea were above the maximum residue limits permitted in foodstuffs (Lin et al., 2018).

Hashmi et al. (2014) determined $\mathrm{Pb}, \mathrm{Cd}, \mathrm{Zn}, \mathrm{Cu}, \mathrm{Cr}$ and Mn levels in eight sea cucumber species from the market in Kota Kinabalu, Sabah. It was concluded that Holothuria leueospilota and Thelenota ananas species pose health risks, whereas Holothoria edulis, Thelenota anax, Actinopyga lecan, Bohadachio vitiens, Stichopus vastus and Phyllophogius spiculata were safe for people consumption. It has been proposed that these six sea cucumber species, which are safe, can be exported (Hashmi et al., 2014).

Jiang et al., (2015) determined $\mathrm{Cu}, \mathrm{Zn}, \mathrm{Cr}, \mathrm{Pb}, \mathrm{Cd}$, As and $\mathrm{Hg}$ levels in the juveniles of Apostichopus japonicus from coastal areas of Bohai and Yellow seas in northern China. They found the average amounts lower than the permissible limits for human consumption except As in $10 \%$ samples exceeded the safety threshold. It is emphasized that better awareness should be paid to toxic heavy metals such as $\mathrm{Pb}, \mathrm{Cd}$, As and $\mathrm{Hg}$ in the future standard monitoring program (Jiang et al., 2015).

On the other hand, the amounts of $\mathrm{Hg}$ in Holothuria (Thymiosycia) arenicola, Holothuria (Lessonothuria) pardalis, Holothuria (Lessonothuria) verrucosa and Holothuria (Halodeima) atra (Ahmed et al., 2018c), and Ohshimella ehrenbergii and Stolus buccalis (Ahmed et al., 2019) from the Karachi coasts in Pakistan do not show any health problems for human consumption. Similarly, Jinadasa et al. (2014) determined $\mathrm{Cu}, \mathrm{Fe}, \mathrm{Zn}, \mathrm{Pb}, \mathrm{Cd}, \mathrm{Co}$, $\mathrm{Cr}$ and $\mathrm{Hg}$ levels in Holothuria edulis, Holothuria atra, Thelenota anax, Holothuria scabra, Holothuria spinifera, Bohadschia sp., Bohadschia similis, Bohadschia marmorata, Actinopyga miliaris and Stichopus chloronotus from the North-western sea of Kalpitiya and Dutch Bay area, Sri Lanka. It was concluded that although the amount of Fe was high in these sea cucumber species, they did not generally pose a health risk for human consumption (Jinadasa et al., 2014).
Rasyid (2017) measured toxic heavy metals Hg, Cd, As and $\mathrm{Pb}$ in the dried sea cucumber Stichopus vastus from Salemo Island in Indonesia. As these metals cannot be detected, it has been stated that it does not pose a threat to human health (Rasyid, 2017).

Actinophyga bannwarth demonstrated higher capability to accumulate $\mathrm{Cd}, \mathrm{Cu}, \mathrm{Ni}$, and $\mathrm{Zn}$ than Holothuria impatiens (Al-Najjar et al., 2018). They showed that $\mathrm{Cu}$, $\mathrm{Mn}, \mathrm{Zn}, \mathrm{Ni}$ and Fe levels in the small sizes $(<25 \mathrm{~cm})$ of these both species were greater than their levels in the large sizes $(>30 \mathrm{~cm})$.

Amounts of the metals in sea cucumber species seemed to decrease with increased distance offshore, a trend presumably related to the proximity of contamination sources. Different amounts of heavy metals in different sea cucumber species have proven to vary temporally, spatially and climatically (Ahmed et al., 2017). They showed that biota sediment accumulation factor (BSAF) values of $\mathrm{Cu}, \mathrm{Fe}, \mathrm{Mn}$ and $\mathrm{Pb}$ for Holothuria arenicola, Holothuria pardalis, Holothuria verrucosa, Holothuria atra, Ohshimella ehrenbergii, Holothuria cinerascens, Stolus buccalis and Holothuria leucospilota were low, indicating the species as de-concentrators. Zn amounts in all these species from Karachi coast in Pakistan was very bio-accumulative (biota concentration factors were higher than 5000, whereas $\mathrm{Cu}, \mathrm{Fe}, \mathrm{Mn}$ and $\mathrm{Pb}$ were considered as bio-accumulative (Ahmed et al., 2017). Ahmed et al. (2017) suggested that these sea cucumber species might be served as good bioindicators. Ahmed and Bat (2020) showed similar result that $\mathrm{Hg}$ levels in Holothuria leucospilota from Karachi coast in Pakistan was very bioaccumulative (BCF > 5000). Since, BSAF values of $\mathrm{Hg}$ for the muscles of Holothuria leucospilota ranged from 1.44 to 1.63 , considered as micro-concentrator, but this value is higher than 2 on the skin of Holothuria leucospilota, it was evaluated as macro-concentrator (Ahmed and Bat, 2020). Moreover, Mohsen et al. (2019) reported that BSAF showed that Apostichopus japonicus was a macro-concentrator for $\mathrm{Cd}$ in China. It was suggested that this sea cucumber species could be regarded as a bio-monitor for Cd (Mohsen et al., 2019).

Fretes et al. (2020) showed that the accumulation of heavy metals in the intestine of Stichopus herrmanni caused damage to villi in the form of necrosis. The body wall of Acaudina leucoproctais apt to absorption and accumulation of heavy metals, which may be considered as a precious bioindicator for assessing and monitoring metals contamination in surrounding seawater (Lin et al., 2018). The amount of $\mathrm{Hg}$ in the muscles of Holothuria leucospilota from Karachi coasts in Pakistan was found to be less than its skin (Ahmed and Bat, 2020).

Al-Najjar et al. (2018) determined that $\mathrm{Zn}, \mathrm{Pb}, \mathrm{Fe}$ and $\mathrm{Mn}$ levels were lower in Actinophyga bannwarth and Holothuria impatiens than in the sediments. It was concluded that it might consider binding of large amounts 
of metals in the sediments and differential mean of regulating these metals in tissues of these sea cucumber species. It is also pointed out that the determination of metal amounts in sediment makes notice regarding the total content not the bioavailable fraction (Al-Najjar et al. 2018). Similarly, Xing and Chia (1997) suggested that Holothuria leucospilota was not a potential bio-indicator organism of $\mathrm{Zn}$ and $\mathrm{Cu}$ in sediment, because of these metal levels in faeces of this species was almost identical to that of the sediment, considering that little or no metal was absorbed through sediment ingestion. Zn amounts in various tissue/organs of Holothuria leucospilota were much higher than that of $\mathrm{Cu}$ (Xing and Chia, 1997).

Warnau et al. (2006) determined $\mathrm{Cd}, \mathrm{Cu}, \mathrm{Fe}, \mathrm{Pb}$ and $\mathrm{Zn}$ levels in Holothuria tubulosa from the Mediterranean Posidonia oceanica ecosystem. It was pointed out that, if Holothuria tubulosa used as a bio-indicator species for surveying and monitoring metal pollution in the Mediterranean Posidonia oceanica seagrass, care should be done to compare only concentrations measured in the same body compartments of individuals collected during the same period of the year. It was noted that, preferably, the body compartments that should be considered for metal analysis are primarily the haemal system and secondarily the gut (Warnau et al., 2006). Finally, they pointed out that since Holothuria tubulosa as a deposit feeder and lives on the sediments, this species could be effectively used to understand for bioindicators available so far for appraising metal pollution in the Posidonia oceanica ecosystem.

\section{Conclusion}

Studies on metal accumulation in sea cucumbers have been carried out for years and have been increasing more recently. Because sea cucumbers change or renew the structure of the water and sediment they are in, they are very important for the benthic region. In addition, many species increase their popularity due to the importance of being consumed and cultivated and being used intensely medically. There are many advantages to using sea cucumbers in marine pollution monitoring studies. The reasons why sea cucumbers are preferred in pollution monitoring studies are that they are spread over very large areas, they are relatively easy to collect, they are easy to maintain in the laboratory, they have enough tissues or organs for analysis. Studies show that many sea cucumber species accumulate heavy metal. Metal accumulation of sea cucumbers is higher in ambient waters than sediment. Many sea cucumber species are also recommended as bioindicators. At the same time, many researchers strongly recommend carrying out monitoring studies with sea cucumbers in the future.

\section{Conflict of interest statement}

We declare that we have no conflict of interest.

\section{References}

Ahmed, Q., Ali, Q. M., \& Bat, L. (2017). Assessment of heavy metals concentration in Holothurians, sediments and water samples from coastal areas of Pakistan (northern Arabian Sea). Journal of Coastal Life Medicine, 5(5), 191-201.

Ahmed, Q., Ali, Q.M. (2014). Abundance and Distribution of Holothuroidea (Echinodermata) with Emphasis on Heavy Metals Accumulation in Organism and Its Habitat. Project: Higher Education Commission of Pakistan, (Grant No. IPFP/HRD/HEC/1688).

Ahmed, Q., Ali, Q.M. (2020). Holothurians from Pakistan: New addition of Holothuria (Theelothuria) notabilis (Ludwig, 1875) and rediscovery of Actinocucumis typica (Ludwig, 1875) from the Karachi coast, northern Arabian Sea. Beche-De-Mer information bulletin, 40, 40-42.

Ahmed, Q., Ali, Q.M., Mazlan, N., Bat, L. (2018b). First record of a-sexual reproduction by fission in Holothuria (lessonothuria) verrucosa (Selenka, 1867) from coastal waters of Karachi, Pakistan. International Journal of Environment and Geoinformatics, 5(1), 29-36.

Ahmed, Q., Bat, L. (2020). Assessment of $\mathrm{Hg}$ in Holothuria (Mertensiothuria) leucospilota (Brandt, 1835) from Karachi coasts, Pakistan. KSÜ Tarım ve Doğa Dergisi 23,(0): $\quad$ xxx-xxx. DOI: 10.18016/ksutarimdoga.vi.715683.

Ahmed, Q., Bat, L., \& Ali, Q. M. (2018c). Analysis of mercury $(\mathrm{Hg})$ in four Holothurians species (PhylumEchinodermata) from Karachi coast-northern Arabian Sea. Aquatic Research, 1(2), 55-63.

Ahmed, Q., Bat, L., \& Ali, Q. M. (2019). Determination of mercury $(\mathrm{Hg})$ in two sea cucumber species Ohshimella ehrenbergii (Selenka, 1868) and Stolus buccalis (Stimpson, 1855) from the Karachi coast. Pakistan Journal of Marine Sciences, 28(1), 55-62.

Ahmed, Q., Poot-Salazar, A., Ali, Q.M., Bat, L. (2018a). Seasonal variation in the length-weight relationships and condition factor of four commercially important sea cucumbers species from Karachi coast- Northern Arabian Sea. Natural and Engineering Sciences, 3(3), 265-281.

Al-Najjar, T., Alshabi, M., Wahsha, M., Abu-Hilal, A. (2018). Trace Metals Concentration of Sea Cucumber (Actınophyga bannwarthii and Holothuria impatıens) from the Red Sea, Gulf of Aqaba. Fresenius Environmental Bulletın, 27(5 A), 3740-3745.

Anonymous (2020a). http://www.marinespecies.org/ accessed 08.04.2020.

Anonymous (2020b). https://www.sealifebase.se accessed 08.04.2020.

Aydin, M. (2008). The commercial sea cucumber fishery in Turkey. SPC Beche de Mer Information Bulletin Issue 28 - October 20.

Balkıs N, Aksu A, Müftüoğlu, AE (2007) Heavy metal pollution of the Turkish shores of the Black Sea. Rapp Comm Int Mer Me'dit 38:230.

Bat, L., Arıc1, E. (2018). Chapter 5. Heavy Metal Levels in Fish, Molluscs, and Crustacea From Turkish Seas and Potential Risk of Human Health. In: Holban AM, 
Grumezescu AM. (Eds.) Handbook of Food Bioengineering, Volume 13, Food Quality: Balancing Health and Disease (pp. 159-196), Elsevier, Academic Press.

Bat, L., Özkan, E. Y. (2019). Heavy Metal Levels in Sediment of the Turkish Black Sea Coast. In I. Management Association (Ed.), Oceanography and Coastal Informatics: Breakthroughs in Research and Practice (pp. 86-107). Hershey, PA: IGI Global. doi:10.4018/978-1-5225-7308-1.ch004

Bat, L., Öztekin, A., Şahin, F., Arıcı, E., Özsandıkçı, U. (2018). An overview of the Black Sea pollution in Turkey. MedFAR., 1(2): 67-86.

Bordbar, S., Anwar, F., Saari, N. (2011). High-Value Components and Bioactives from Sea Cucumbers for Functional Foods-A Review. Mar. Drugs, 9, 17611805; doi:10.3390/md9101761.

Bryan, G.W. (1976). Some aspects of heavy metal tolerance in aquatic organisms. In: Lockwood (Ed.), Effects of Pollutants on Aquatic organisms (pp. 7-34) A.P.M. Cambridge University Press.

Burak, S., Ünlü, S., Gazioğlu, C. (2009). Environmental stress created by chemical pollution in the Sea of Marmara (Turkey). Asian Journal of Chemistry, Vol. 21(4). 3166-3174

Conand, C., Purcell, S., Gamboa, R. (2013). The IUCN Red List of Threatened Species 2013.

Denton, G. R., Concepcion, L. P., Wood, H. R., Eflin, V. S., Pangelinan, G. T. (1999). Heavy metals, PCBs and PAHs in marine organisms from four harbor locations on Guam. Water and Environmental Research Institute of the Western Pacific, University of Guam.

Du, H., Bao, Z., Hou, R., Wang, S., Su, H., et al. (2012). Transcriptome Sequencing and Characterization for the Sea Cucumber Apostichopus japonicus (Selenka, 1867). PLoS ONE, 7(3), e33311. doi:10.1371/journal.pone.0033311

Farrington, J.W., Davis, A.C., Tripp, B.W., Phelps, D.K., Galloway, W.B. (1987). Mussel WatchMeasurements of Chemical Pollutants in Bivalves as One Indicator of Coastal Environmental Quality. T.P. Boyle, (Ed.), New Approaches to Monitoring Aquatic Ecosystems (pp. 125-139), American Society for Testing and Materials, Philadelphia.

Fretes, C. C., Kakisina, P., Rumahlatu, D. (2020). Concentration of Heavy Metal $\mathrm{Hg}, \mathrm{Au}$, and $\mathrm{Fe}$ in Sediments, Water, and Tissue Damage of Golden Sea Cucumber Stichopus herrmanni (Semper, 1868)(Holothuroidea; Stichopodidae) in Kayeli Bay, Indonesia. Acta Aquatica Turcica, 16(1), 113-123.

Gao, F., Tan, J., Sun, H., Yan, J. (2014). Bacterial diversity of gut content in sea cucumber (Apostichopus japonicus) and its habitat surface sediment. Journal of Ocean University of China, 13(2), 303-310.

Gazioğlu, C. (2018). Biodiversity, Coastal Protection, Promotion and Applicability Investigation of the Ocean Health Index for Turkish Seas. International Journal of Environment and Geoinformatics (IJEGEO), 5(3), 353-367.

Haider, M.S., Sultana, R., Jamil, K., Lakhte, Z., Tarar, O.M., Shirin, K., et al. (2015). A study on proximate composition, amino acid profile, fatty acid profile and some mineral contents in two species of sea cucumber. J Anim. Plant. Sci., 25(1), 168-75.

Hashmi, M. I., Thilakar, R., bin Syed Hussein, M. A., Hoque, Z. (2014). Determination of seven heavy metals in eight species of Sea Cucumbers. Sci Int, 26(1), 261-262.

Higgins, M. (2000). Sea cucumbers in a deep pickle. Environmental News Network, 30.

Isgören-Emiroglu, D., Günay, D. (2007). The Effect of Sea Cucumber Holothuria tubulosa(G., 1788) on Nutrient and Sediment of Aegean Sea Shores. Pakistan Journal of Biological Sciences, 10(4), 586589.

Ismail, H., Punithamalar, A., Sakian, NIM, \& Hashim, R. (2004). Heavy Metal Concentration in Body Walls of Malaysian Sea Cucumbers. Jurnal Sains Kesihatan Malaysia (Malaysian Journal of Health Sciences), 2(1), 75-79.

Jiang, H., Tang, S., Qin, D., Chen, Z., Wang, J., Bai, S., Mou, Z. (2015). Heavy metals in sea cucumber juveniles from coastal areas of Bohai and Yellow Seas, North China. Bulletin of environmental contamination and toxicology, 94(5), 577-582.

Jinadasa, B. K., Samanthi, R. I., Wicramsinghe, I. (2014). Trace metal accumulation in tissue of sea cucumber species; North-Western Sea of Sri Lanka. American Journal of Public Health Research, 2(5A), 1-5.

Lane, D. (2008). Echinodermata. In p. 129-143, Davison, G.W.H.; Ng, P.K.L.; Ho, H.C., 2008. The Singapore Red Data Book: Threatened plants and animals of Singapore. Singapore: The Nature Society, 285pp.

Lin, S. J., Chen, L. F., Jia, Y. B., Xiao, H. L., Xue, Y. P., Zheng, Y. G. (2018). Distribution and chemoenzymatic removal of heavy metals in sea cucumber Acaudina leucoprocta. Food Science and Technology Research, 24(2), 223-229.

Lin, S., Xue, Y., San, E., Keong, T.C., Chen, L., Zheng, Y. (2017) Extraction and Characterization of Pepsin Soluble Collagen from the Body Wall of Sea Cucumber Acaudina leucoprocta, Journal of Aquatic Food Product Technology, 26:5, 502-515, DOI: 10.1080/10498850.2016.1222560

Mohammadizadeh, M., Bastami, K. D., Ehsanpour, M., Afkhami, M., Mohammadizadeh, F., Esmaeilzadeh, M. (2016). Heavy metal accumulation in tissues of two sea cucumbers, Holothuria leucospilota and Holothuria scabra in the northern part of Qeshm Island, Persian Gulf. Marine pollution bulletin, 103(12), 354-359.

Mohsen, M., Wang, Q., Zhang, L., Sun, L., Lin, C., Yang, H. (2019). Heavy metals in sediment, microplastic and sea cucumber Apostichopus japonicus from farms in China. Marine pollution bulletin, 143, 42-49.

Ober, A.G., Gonzáles, M., Maria, I.S. (1987). Heavy Metals in Molluscan, Crustacean, and Other Commercially Important Chilean Marine Coastal Water Species. Bull. Environ. Cont. Toxicol., 38, 534539.

Özer, N. P., Mol, S., Varlık, C. (2004). Effect of the handling procedures on the chemical composition of sea cucumber. Turkish journal of fisheries and aquatic sciences, 4(2), 71-74. 
Pangestuti, R., Arifin, Z. (2018). Medicinal and health benefit effects of functional sea cucumbers. Journal of traditional and complementary medicine, 8(3), 341351.

Phillips, D.J.H., Rainbow, P.S. (1994). Biomonitoring of trace aquatic contaminants. Environmeantal Management Series, Chapman \& Hall, London.

Purcell, S. W., Conand, C., Uthicke, S., Byrne, M. (2016). Ecological roles of exploited sea cucumbers. In Oceanography and marine biology (pp. 375-394). CRC Press.

Purcell, S.W. (2010). Managing sea cucumber fisheries with an ecosystem approach to managing sea cucumber fisheries, In Lovatelli AM, Vasconcellos and Yimin Y (eds). FAO Fisheries and Aquaculture Technical Paper (pp. 157) No.520. Rome.

Purcell, S.W., Samyn, Y. \& Conand, C. (2012). Commercially important sea cucumbers of the world. FAO Species Catalogue for Fishery Purposes. No. 6. Rome, FAO. 2012. 150 pp. 30 colour plates.

Rasyid, A. (2017). Nutritional Value and Heavy Metals Contents of the Dried Sea Cucumber Stichopus Vastus From Salemo Island, Indonesia. Jurnal Ilmu dan Teknologi Kelautan Tropis, 9(2), 739-746.

Ridzwan, B.H. (2007). Sea Cucumbers, A Malaysian Heritage, 1st ed. Research Centre of International Islamic University Malaysia (IIUM): Kuala Lumpur Wilayah Persekutuan, Malaysia.

Samyn, Y. (2013). The IUCN Red List of Threatened Species 2013.

Toral-Granda, V., Lovatelli, A., Vasconcellos, M. (2008). Sea Cucumbers. A Global Review on Fishery and Trade. FAO Fisheries Technical Paper. No. 516, FAO, Rome.

Turk Culha, S., Dereli, H., Karaduman, F. R., Culha, M. (2016). Assessment of trace metal contamination in the sea cucumber (Holothuria tubulosa) and sediments from the Dardanelles Strait (Turkey). Environmental Science and Pollution Research, 23(12), 11584-11597.

Warnau, M., Dutrieux, S., Ledent, G., Rodriguez y Baena, A. M., Dúbois, P. (2006). Heavy metals in the sea cucumber Holothuria tubulosa (Echinodermata) from the Mediterranean Posidonia oceanica ecosystem: body compartment, seasonal, geographical and bathymetric variations. Environmental bioindicators, 1(4), 268-285.

Wen, J., Hu, C. (2010). Elemental composition of commercial sea cucumbers (holothurians). Food Additives and Contaminants, 3(4), 246-252.

Xing, J., Chia, F. S. (1997). Heavy metal accumulation in tissue/organs of a sea cucumber, Holothuria leucospilota. Hydrobiologia, 352(1-3), 17-23.

Zamora, L. N., Yuan, X., Carton, A. G., Slater, M. J. (2016). Role of deposit-feeding sea cucumbers in integrated multitrophic aquaculture: progress, problems, potential and future challenges. Reviews in Aquaculture, 10(1), 57-74. 